Article

\title{
Evaluating Local Attractiveness for Tourism and Recreation-A Case Study of the Communes in Brzeski County, Poland
}

\author{
Agnieszka Ziernicka-Wojtaszek *(D) and Magdalena Malec
}

check for updates

Citation: Ziernicka-Wojtaszek, A.; Malec, M. Evaluating Local Attractiveness for Tourism and Recreation-A Case Study of the Communes in Brzeski County,

Poland. Land 2022, 11, 39.

https://doi.org/10.3390/land 11010039

Academic Editors: Antonio Raschi and Hossein Azadi

Received: 23 November 2021

Accepted: 22 December 2021

Published: 28 December 2021

Publisher's Note: MDPI stays neutral with regard to jurisdictional claims in published maps and institutional affiliations.

Copyright: (c) 2021 by the authors. Licensee MDPI, Basel, Switzerland. This article is an open access article distributed under the terms and conditions of the Creative Commons Attribution (CC BY) license (https:// creativecommons.org/licenses/by/ $4.0 /)$.

\begin{abstract}
Department of Ecology, Climatology and Air Protection, Faculty of Environmental Engineering and Land Surveying, University of Agriculture in Kraków, 30-059 Kraków, Poland; magdalena.malec@urk.edu.pl

* Correspondence: agnieszka.ziernicka-wojtaszek@urk.edu.pl; Tel.: +48-12-662-4012
\end{abstract}

\begin{abstract}
For many regions and communes, the development of tourism offers opportunities for economic revival, the stimulation of local entrepreneurship and, as a result, increased budget revenues. Before such objectives can be successfully pursued, however, it is necessary to carefully consider to what degree the conditions present in a particular area are conducive to the development of tourism there, including its tourism resources and the existing state of development. This study analyzes the attractiveness of the seven communes making up Brzeski County (Lesser Poland Voivodeship, Poland) for tourism and recreation. The potential of the communes in this largely rural county was characterized using Gołembski's index, based on multivariate comparative analysis, assessing the natural and man-made features and the degree of development of each of the communes. This analysis was further complemented using Wejchert's impression curve, assessing visual attractiveness along selected routes in two of the communes. Of the seven communes analyzed, the Commune of Brzesko was found to have the most extensively developed services, hotel and food-service infrastructure, to be home to many historic buildings and to have a relatively high municipal budget. The Commune of Iwkowa, in turn, which scored lowest in terms of Gołembski's index (mainly due to its underdeveloped infrastructure, few historic buildings and the fact that it is crossed by a major transit route), was nevertheless found to score significantly higher than Brzesko in terms of Wejchert's impression curve. These findings confirm that the beauty of the landscape is not always well correlated with tourism development potential. We conclude that such a combination of methods should to be applied to reliably and comprehensively evaluate the relative attractiveness of different parts of a given region for tourism and recreation, for instance so as to inform planning decisions and the allocation of funding.
\end{abstract}

Keywords: attractiveness for tourism; landscape; evaluation methods; Poland

\section{Introduction}

Since the start of the 21st century, the tourism industry has experienced a worldwide boom which continues to the present day-setting aside the exceptional impact of the COVID-19 pandemic [1,2]. The rising disposable incomes now being enjoyed in many countries have been driving increased spending on non-material goods, contributing in many locations to increased income for the local authorities and hospitality-related businesses (the accommodation and food-service sectors) in areas of tourist interest [3,4]. However, significant growth in tourism is not possible everywhere, only in locations which are deemed worth visiting by significant numbers of people. Evaluating a region's attractiveness to tourism, therefore, involves assessing which of its natural and man-made resources can, and indeed do, successfully draw people's attention and attract visitors as well as tourism-industry investors [5-7]. Such evaluations provide information that is then useful in a range of decisions regarding planning, funding allocation, etc.

In Poland, the basic planning documents that are prepared at the lowest level of spatial planning (that of the gmina, or commune) are land-use studies, which are official documents 
drawn up in order to guide the commune's spatial policy, and local zoning plans, which are acts of local law which implement the directions of spatial development identified in the land-use studies. Existing scientific case-studies examining particular communes' tourism resources, advantages, and degree of tourism development may serve as useful materials in the development of the aforementioned documents [8].

Moreover, such scientific case-studies may prove useful in tourism-related didactics. For example, the textbook Regiony turystyczne (Tourism Regions) used in Poland to teach the subject on the university level deals with theoretical issues of regionalization, presents the world's macro-regions for tourism, describes the tourism economy in regions and the creation of tourism products, and discusses the basics of creating development strategies and the principles of tourism control. The publication contains 30 examples from all over the world, illustrating the above-mentioned theoretical issues; such case-studies juxtapose theoretical findings of tourism-related research with the practice of everyday life [9].

The degree of a given region's attractiveness for tourism may find expression in various oral, written and other reports disseminated in the media by visitors to attractive locations, frequently participating in specific activities such as sports, nature exploration or sightseeing. There are certain well-established lists of sites and historic monuments that have long been regarded as "must-sees" for all sophisticated travelers, as well as more short-term fashions that temporarily boost the popularity of specific locations. However, the impressions of individual tourists or groups as related in their personal accounts of their experiences, albeit certainly an important source of information, will not be the subject of analysis here [10-13]. Rather, in order to more reliably and less subjectively assess the degree to which tourism and recreation are developed in a given region and the potential for further growth there, it is important to examine and estimate the resources that crucially underlie such attractiveness both to potential visitors, and to potential investors in tourism and recreation infrastructure. This can be carried out through a range of methods [14], including for instance the point-valuation method and the modelling method.

Methods based on multivariate comparative analysis, such as that of Gołembski [15], are increasingly being applied in studies which describe the attractiveness of a region in terms of a broad collection of features. Such methods usually begin by selecting a range of specific features in terms of which different (sub)regions will be evaluated (e.g., the numbers of existing attractions and existing hospitality-industry establishments, various aspects of infrastructure, financial factors, various environmental factors and visual attractiveness). A matrix is then created of observed values for specific features or factors, these values are standardized, the features/factors may be assigned differing weights, and then specific scores may be calculated-including a final synthetic score/index of overall attractiveness for each subregion. This approach makes it easy to compare several subregions-for example, in Poland, the different communes making up a county, the different counties making up a voivodeship, or the different communes that lie a given physical geographical, historical or administrative area. The results of such comparative analysis may then channel into decision-making about directing funds to underdeveloped regions, to those seen as the most attractive, or to others selected by decision-makers on the basis of objective assessment of tourism and recreation resources and attractions [16-18].

However, assessing the aesthetic attractiveness of landscapes and scenery is widely known to be extremely difficult in terms of objectivity and methodology [19-24], as the perception of scenery depends on many factors, many of them highly subjective. People evaluate landscapes on both the conscious and subconscious levels, invoking certain remembered patterns linked to past experiences or preferences [25]. However, the perceived attractiveness of a given region's landscape is extremely important, since it has a significant impact on decisions concerning tourism and recreation. While ratings of attractiveness will always be inherently subjective, it is nonetheless generally assumed that certain groups do perceive and experience certain types of surroundings in similar ways [26]. To this end, seeking to evaluate the attractiveness of particular landscapes, we can strive to identify certain quite universal aesthetic categories that contribute to impressions of beauty: these 
may be taken to include the features of "regularity, restraint, symmetry, proportion and balance" [27], or more broadly "harmony, restraint, sustainability, lushness, simplicity, depth, peace and majesty" [28].

One of the many ways of evaluating the visual impact of landscapes is Wejchert's "impression curve" method $[29,30]$, used to identify both attractive locations and those which require intervention in order to bolster their aesthetic values. Although the method was originally developed for urban spaces [29,30], it has also been adapted and used to evaluate rural areas [31]. As a theorist of urban composition, Wejchert [32] paid particular attention to the physiognomic aspects of landscapes. When assessing a landscape, it is indeed important to consider the interplay between the physiognomy of the space and how it is perceived, as is inseparably tied up with human mentality and behavior [29,33]. Most studies concerning the attractiveness and utility of a given region use methods focusing on parameters such as local infrastructure, transport, number of protected areas, accommodation, food-service infrastructure and other tourist attractions. However, tourists are increasingly focusing on aesthetic attractiveness, which is closely tied with perceived naturalness and beauty [34-38].

The objective of this study was to evaluate the attractiveness of the seven communes making up Brzeski County (Lesser Poland Voivodeship, Poland) for tourism and recreation. This evaluation was performed by means of three methods: inventory-taking, Gołembski's [15] multivariate comparative index, and Wejchert's [32] impression curve.

\section{Materials and Methods}

Territorial administration in Poland is a three-tier system consisting of 16 provinces or voivodships, which are subdivided into counties, which in turn are further subdivided into communes. The basic spatial unit adopted in this study is the commune, as it is the smallest unit for which reliable statistical data can be obtained. Polish communes are further classified as rural, urban, or urban-rural communes.

Brzeski County is located in the north-eastern part of the Lesser Poland Voivodeship, between the cities of Kraków and Tarnów. Covering $591 \mathrm{~km}^{2}$ in total area, Brzeski County consists of seven communes. Two of them (Brzesko and Czchów) are classified as urban-rural communes, while the remaining five (Borzęcin, Dębno, Gnojnik, Iwkowa and Szczurowa) are classified as rural communes (Figure 1). The communes to the north are mainly characterized by agricultural production. The central part of the county, i.e., the communes of Brzesko and Dębno, are distinguished by the highest degree of urbanization and non-agricultural development. The southern areas of the county are distinguished by their scenic qualities. According to Kondracki's physical and geographic regionalization, the research area should be treated as part of the Carpathian and Subcarpathian provinces [39].

The statistical material used for the study was taken from the Local Data Bank maintained by Statistics Poland (GUS) [40], as well as gathered from certain available studies on individual communes, and through local site visits. These data were then used to perform a multidimensional comparative analysis, largely following the method developed by Gołembski [15].

Namely, in line with this approach, the overall principle was adopted that the more features (reflecting conditions necessary for development of tourism) were taken into account, the more accurately each area under study would be characterized. We further assumed that these features should be presented in the form of relative indexes, which make it possible to determine their rank and assign them specific weights; that they should largely be expressed in terms of spatial units (e.g., per $\mathrm{km}^{2}$ ) or groups of people (e.g., per 10,000 inhabitants), and that features should be selected in such a way that they can be grouped into certain subdomains, and then broad domains.

Overall, then, we strove to evaluate the degree to which conditions in each area are conducive to tourism development by creating and calculating two synthetic indicatorsone intended to reflect the tourism attractiveness of each commune for tourists, the second 
to reflect its tourism attractiveness for potential investors (which we refer to as the two "domains" of attractiveness). This separation into two main domains is meant to reflect the fact that these two perspectives differ quite fundamentally. This might be summed up, in somewhat colloquial terms, as follows: investors do not want to spend leisure time; rather, they want to earn money from those spending leisure time.
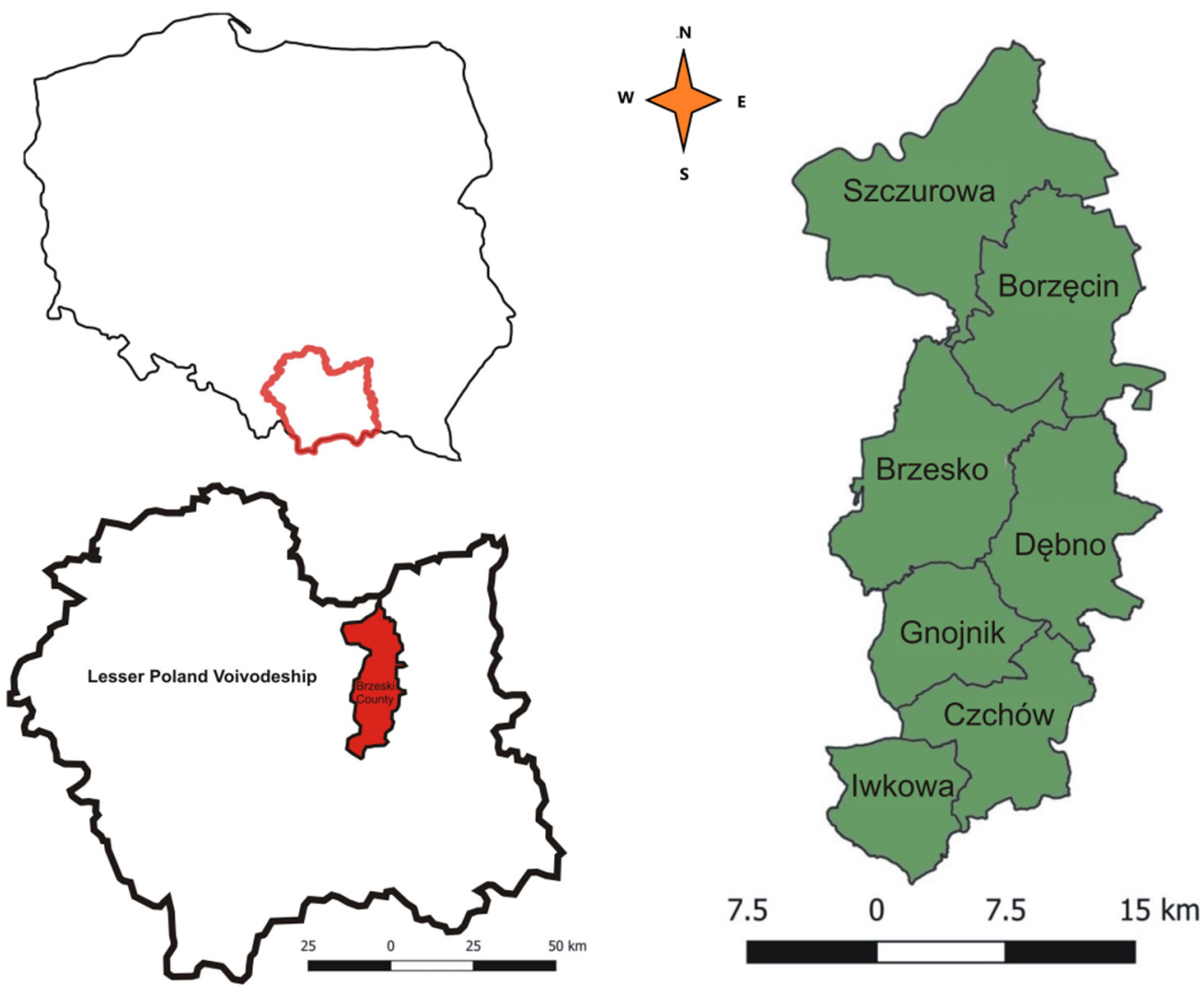

Figure 1. Location of Brzeski County within the Lesser Poland Voivodship and its administrative division into seven communes.

We further assumed that the first domain-attractiveness to tourists—is comprised of five basic sets of factors (or "subdomains"), namely:

- The extant tourist attractions;

- The state of the natural environment;

- The environmental protection efforts;

- Transport links;

- The base of accommodation, catering and accompanying facilities.

The second domain-attractiveness for investors - on the other hand, is defined as the resultant of the following four sets of factors (subdomains):

- The state of service infrastructure;

- The state of technical infrastructure;

- The social relations among society;

- The condition of commune finances (Table 1).

Each of these subdomains, in turn, is characterized by the values of a number of different features or variables (Tables 2 and 3). For each such feature, our research procedurestill following the approach of Gołembski [15]—involved the unification of the direction of scale preferences (i.e., transforming downwards-entailing scales into upwards-entailing ones) and the normalization of the values. 
Table 1. Domains and subdomains within which diagnostic features and weights were selected (applying the approach of Gołembski [15]).

\begin{tabular}{cccc}
\hline Domains & Weight & Subdomains & Weights \\
\hline & & Tourist attractions & 0.40 \\
Attractiveness for tourists & \multirow{2}{*}{0.50} & State of the environment & 0.15 \\
& & Environmental protection & 0.15 \\
& & Transport links & 0.10 \\
& & Accommodation, catering and & 0.20 \\
& & accompanying facilities & 0.32 \\
Attractiveness for investors & \multirow{2}{*}{0.50} & Service infrastructure & 0.25 \\
& & Technical infrastructure & 0.23 \\
& & Societal relations & 0.20 \\
\hline
\end{tabular}

Table 2. Diagnostic features in the domain of attractiveness to tourists and their weighting.

\begin{tabular}{|c|c|c|c|c|}
\hline Domain of Analysis & Number & Feature & Unit of Measurement & Weight \\
\hline \multicolumn{5}{|c|}{ Tourist attractions } \\
\hline & 1. & forest area & ha & 0.25 \\
\hline & 2. & arable area & ha & 0.05 \\
\hline & 3. & number of natural monuments & number of sites & 0.15 \\
\hline & 4. & museums & number of sites & 0.10 \\
\hline & 5. & major sights & number of sites & 0.15 \\
\hline & 6. & length of tourist trails & $\mathrm{km} / \mathrm{km}^{2}$ & 0.20 \\
\hline & 7. & $\begin{array}{l}\text { number of cultural events taking place in } \\
\text { the county }\end{array}$ & number of events $/ 365^{*} 100$ & 0.10 \\
\hline & & State of the env & nent & \\
\hline & 8. & $\begin{array}{l}\text { amount of communal waste collected } \\
\text { during the year }\end{array}$ & metric tons & 0.40 \\
\hline & 9. & $\begin{array}{l}\text { share of biologically treated wastewater in } \\
\text { amount of wastewater requiringcleansing }\end{array}$ & $\%$ & 0.60 \\
\hline & & Environmental & tion & \\
\hline & 10. & $\begin{array}{l}\text { ratio of the capacity of wastewater } \\
\text { treatment plants requiring treatment }\end{array}$ & $\mathrm{m}^{3} /$ day & 0.60 \\
\hline & 11. & $\begin{array}{l}\text { illegal landfill sites removed during the } \\
\text { year }\end{array}$ & number of sites & 0.40 \\
\hline \multirow{22}{*}{ Attractiveness for tourists } & \multicolumn{4}{|c|}{ Transport links } \\
\hline & 12. & length of regional roads & $\mathrm{km} / \mathrm{km}^{2}$ & 0.35 \\
\hline & 13. & length of national roads & $\mathrm{km} / \mathrm{km}^{2}$ & 0.35 \\
\hline & 14. & number of railway stations & number $/ \mathrm{km}^{2}$ & 0.30 \\
\hline & \multicolumn{4}{|c|}{ Accommodation, catering and accompanying facilities } \\
\hline & 15. & hotels & number of sites & 0.12 \\
\hline & 16. & pensions & number of sites & 0.10 \\
\hline & 17. & hostels & number of sites & 0.04 \\
\hline & 18. & resorts & number of sites & 0.05 \\
\hline & 19. & guestrooms & number of sites & 0.05 \\
\hline & 20. & ecotourism farms & number of sites & 0.06 \\
\hline & 21. & restaurants & number of sites & 0.10 \\
\hline & 22. & cafes & number of sites & 0.08 \\
\hline & 23. & bars & number of sites & 0.05 \\
\hline & 24. & other catering establishments & number of sites & 0.06 \\
\hline & 25. & sports fields & number of sites & 0.05 \\
\hline & 26. & gyms & number of sites & 0.04 \\
\hline & 27. & swimming pools & number of sites & 0.04 \\
\hline & 28. & bathing sites & number of sites & 0.04 \\
\hline & 29. & winter-sports equipment rentals & number of sites & 0.04 \\
\hline & 30. & rentals of scuba equipment & number of sites & 0.04 \\
\hline & 31. & bicycle rentals & number of sites & 0.04 \\
\hline
\end{tabular}


Table 3. Diagnostic features in the domain of attractiveness for investors and their weighting.

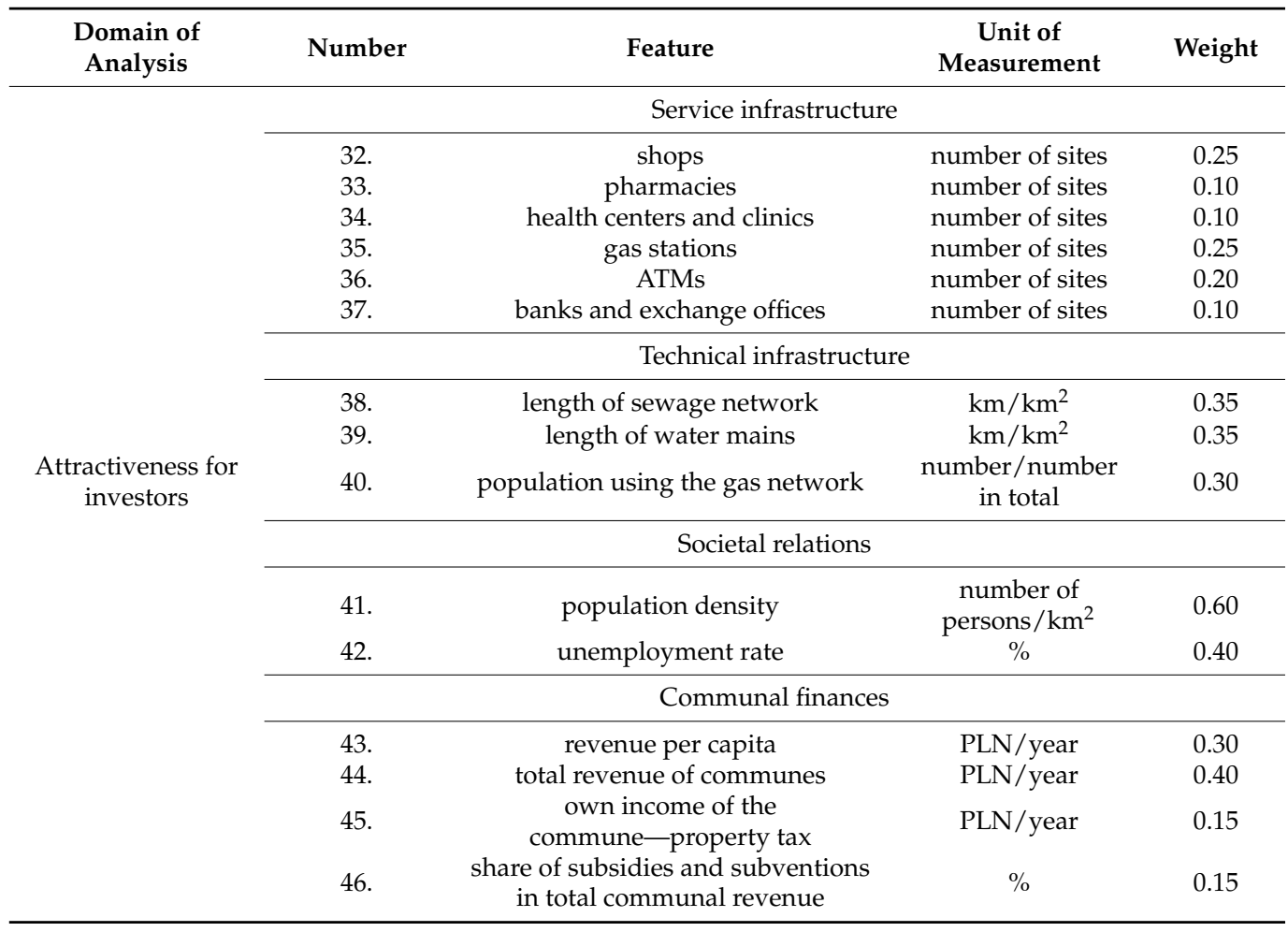

Weights were then assigned separately to each domain, each subdomian, and each feature. The use of such weights reflects the assumption that the individual variables are partial evaluation criteria, which contribute unevenly to how a given area is perceived and evaluated overall. We therefore adopted a system of varied weights meant to reflect these different degrees of contribution. While recognizing that any such system of weights carries an inherent degree of subjectivity, we modeled our weights very closely on the weighting system used in Gołembski [15] (where they are justified based on expert experience and extensive evaluation of tourist attractiveness of various areas in Poland). Moreover, it may be assumed that taking such a considerable number of features (46) into consideration in our study may help counterbalance the effects of any possible erroneous assumptions reflected in the weighting system, and so the results will reflect reality more closely than if equal weights had simply been assigned to each feature. An assumption of equal weights was adopted only at the highest level of generalization, i.e., in the case of the two top-level domains (each being assigned a weight of 0.5 ).

Among the various subdomains, a total of 46 diagnostic features (variables) were identified and standardized so that all of them were measured on upward-entailing scales (whereby an increase in the value of the independent variable leads to an increase in the value of the dependent variable). This was performed by an operation of "subtraction from the maximum": the values obtained for such a feature in a given commune were subtracted from the maximum value of that same feature obtained among the whole group of communes studied.

Next, the diagnostic variables were normalized according to Formula (1), i.e., the value of each indicator was divided by the reference value, which in this case was the maximum recorded value for that particular feature, among all the communes examined [15]:

$$
\mathrm{n}_{\mathrm{ij}}=\frac{\mathrm{y}_{\mathrm{ij}}}{\mathrm{y}_{\mathrm{j}} \mathrm{max}}
$$

where:

$n_{i j}$-normalized value of the $j$-th indicator in the $i$-th commune; 
$y_{i j}$-value of $j$-th indicator in the $i$-th commune;

$y_{j}$ max-maximum value of the $j$-th indicator among all communes analyzed.

The values of the resulting normalized indicators fall in the range from 0 to 1 , with the value of 1 meaning that the analyzed commune exhibits $100 \%$ of the model (maximum) value adopted for this feature [15]. The purpose of such normalization is to enable a set of diagnostic features, which are predominantly expressed in different units of measurement and fall within different numerical ranges, to be used as partial, composite criteria for multivariate evaluation of a complex phenomenon [41]. The normalization procedure transforms absolute values into relative ones, expressed without units, falling within a uniform range. In the next stage the diagnostic variables were assigned weights, and then the synthetic measure for each subdomain was calculated using Formula (2) [42].

$$
M d_{i}=\sum_{j=1}^{n} w_{j} \cdot n_{i j}
$$

where:

$M d_{i}$ - synthetic measure for the subdomain $\mathrm{d}$ in the $i$-th commune;

$w_{j}$-weight of the $j$-th score in subdomain $d_{i} ;$

$n_{i j}$-normalized value of the $j$-th score in the $i$-th commune.

In the domain of attractiveness to tourists, the features selected as variables included the number of touristic attractions (sites, monuments), the length of tourist routes, the number of accommodation catering and accompanying facilities (Table 2).

For attractiveness to investors, in turn, the diagnostic features were selected to characterize the service, technical and social infrastructure necessary for the operation of tourism in the area-including such features as the number of shops, length of the sewage system and income factors (Table 3).

Next, a composite indicator/score for each of the two domains was calculated using the Formula (3)

$$
M S_{i}=\sum_{k=1}^{l} W_{k} \cdot M d_{i}
$$

where:

$k$ - the number of the domain $(k=1,2)$;

$W_{k}$-the weight for the $k$-th domain;

$M S_{i}$ - the synthetic score for the domain in the $i$-th commune.

In the final stage of calculation, all the while following Golembski's [15] method of multivariate comparative analysis, based on these two values (estimating the given commune's attractiveness for tourists and attractiveness for investors) a synthetic score of general determinants of tourism development—-the "Gołembski index" — was calculated for each of the communes of Brzeski County. Figures showing the spatial variation of the study results were created using the QGIS software (see the flow-chart in Figure 2).

Next, this analysis of the communes' attractiveness was supplemented by an analysis of the aesthetics of their landscapes. Here we adopted Wejchert's impression curve method [32]. In recent years, modern societies have been placing increasing emphasis on landscape aesthetics [43]. The landscape affects us on many levels, creating positive or negative relationships, contributing to individual evaluations of the surroundings. However, assessments in terms of aesthetics are subjective and ambiguous, as are the definitions of landscape itself [44-46]. According to [47], subjective evaluations of the landscape are a product of the human mind and help us grasp the visual aesthetics as well as the nature of the landscape under study. The visual landscape comprises both natural and cultural elements. Although the proposed assessment is fundamentally subjective, it is assumed that certain groups of observers will nevertheless respond to stimuli in a similar way. According to Kupidura et al. [48], the graph of deviation from the average response is close to the normal distribution curve. 
Selection of the basic spatial unit

considered in the

study - the commune

(gmina)

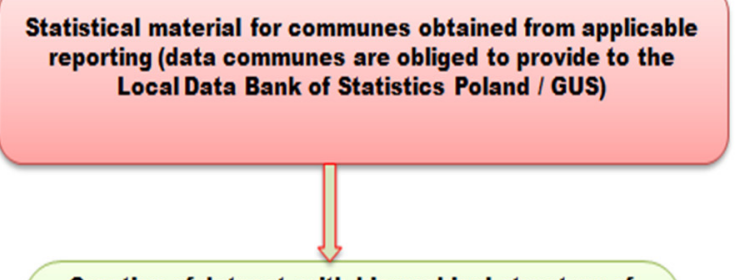

Creation of dataset, with hierarchical structure of diagnostic features (indicators):

2 domains (attractiveness for tourists, attractiveness for investors)

9 subdomains (five subdomains in the first domain, four in the second)

46 features (indicators) - from 2 to 17 in each subdomain

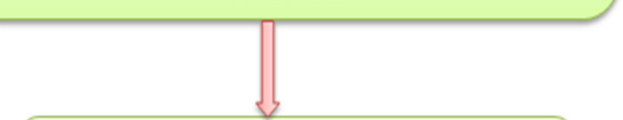

Weight assignment - weights were assigned

separately to each domain, subdomain, and feature

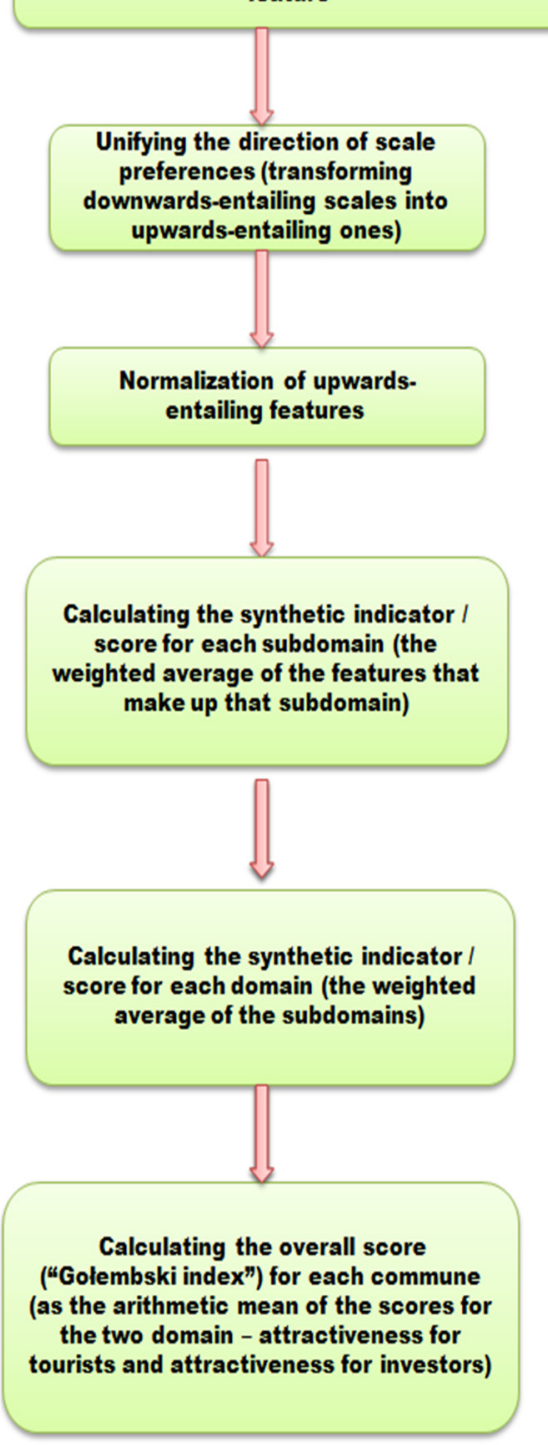

Figure 2. Flow-chart illustrating the application of Gołembski's [15] method of multivariate comparative analysis—calculating the "Gołembski index" of overall attractiveness to tourism development. 
Recognizing that the space around us is truly a space-time continuum, Wejchert [29,30,32] developed a method for analyzing the relationship and interplay between space, time and the observer's impressions. Such an "impression curve" allows us to represent graphically the aesthetic experience at the moment of perception of a given piece of landscape or view. A modification of the method proposed by Cymerman et al. [31] for assessing rural landscapes is used in this paper, in order to increase its objectivity. This modification proposed by Cymerman et al. [31] introduces the scoring of individual evaluated elements presented in Table 4.

Table 4. Criteria used for assessing the aesthetic value of rural landscapes.

\begin{tabular}{|c|c|c|c|c|}
\hline \multirow[b]{2}{*}{ Points } & \multicolumn{4}{|c|}{ Evaluation Criteria } \\
\hline & Degree of Diversity & Level of Devastation & $\begin{array}{l}\text { Infrastructure } \\
\text { Saturation }\end{array}$ & Compositional Harmony \\
\hline 0 & $\begin{array}{l}\text { Monotonous, } \\
\text { homogeneous } \\
\text { landscape }\end{array}$ & $\begin{array}{c}\text { More than } 50 \% \text { of the } \\
\text { area devastated }\end{array}$ & $\begin{array}{l}\text { Infrastructure elements } \\
\text { account for more than } \\
50 \% \text { of the area }\end{array}$ & No harmony \\
\hline 1 & $\begin{array}{c}\text { Monotonous landscape } \\
\text { with individual } \\
\text { enlivening elements }\end{array}$ & $\begin{array}{l}\text { Damaged areas cover } \\
10 \text { to } 50 \% \text { of the terrain }\end{array}$ & $\begin{array}{c}\text { Individual } \\
\text { infrastructure elements } \\
\text { that cover } 10-50 \% \text { of } \\
\text { the area in sight }\end{array}$ & $\begin{array}{l}\text { Some of the elements are } \\
\text { compositionally good, others are } \\
\text { not, e.g., they fit into the profile, } \\
\text { and there is a lack of } \\
\text { composition with the vegetation }\end{array}$ \\
\hline 2 & $\begin{array}{l}\text { Large variety of } \\
\text { landscape, many } \\
\text { individual trees, } \\
\text { groups of shrubs }\end{array}$ & $\begin{array}{l}\text { Damaged areas cover } \\
\text { up to } 10 \% \text { of the terrain }\end{array}$ & $\begin{array}{l}\text { Individual } \\
\text { infrastructure elements } \\
\text { in sight cover less than } \\
10 \% \text { of the area }\end{array}$ & $\begin{array}{l}\text { Most of the elements are } \\
\text { compositionally good, only } \\
\text { some need repair }\end{array}$ \\
\hline 3 & - & $\begin{array}{l}\text { Undeveloped } \\
\text { landscape }\end{array}$ & - & $\begin{array}{l}\text { All elements are compositionally } \\
\text { good, infrastructure elements are } \\
\text { integrated with the profile and } \\
\text { vegetation }\end{array}$ \\
\hline
\end{tabular}

Source: Cymerman et al. [31], Czubaszek et al. [49].

When choosing a tourist destination, modern-day tourists take into account not only the infrastructure but also the aesthetics of the surrounding landscape. Therefore, we undertook an aesthetic evaluation of two communes that had been found to exhibit extreme values in terms of tourism development. The aesthetic evaluation of a landscape is closely related to its perception, i.e., the conscious and subconscious perception and comparison of perceived elements. This process takes place in the human mind and is closely related to many conditions, such as origin, age, education, previous experiences and emotional and physical state. This evaluation is in fact subjective, but the theory of aesthetics demonstrates that certain elements may be perceived and evaluated in a broadly similar way by selected groups of people. One such evaluation method is known as Wejchert's curve. It allows neighboring landscapes to be compared and evaluated by assigning points for the degree of landscape diversity, level of devastation, infrastructure saturation, and harmony of composition. These elements are generally accepted categories of landscape aesthetics (see the flow-chart in Figure 3).

Wejchert's impression curve method was applied only to two of the seven communesthe one scoring highest and the one scoring lowest in terms of the overall Gołembski index. To this end, four different routes were mapped out in each of the two communes, intended to best illustrate the nature of their landscape and aesthetic value. In the Brzesko Commune, Route no. 1 leads through the villages of Jasien-Jadowniki-Sterkowiec-Wokowice with a length of about $10 \mathrm{~km}$. Route no. 2 from Wokowice through Szczepanów-MokrzyskaBucze to Zalesie with a length of about $13 \mathrm{~km}$. Route no. 3 is $7.5 \mathrm{~km}$ long from Zalesie through Brzesko to Okocim. The last route, no. 4, $7.5 \mathrm{~km}$ long, leads from the village of Okocim to Poreba Spytkowska. In the Iwkowa Commune, in turn, Route no. 1 with a 
length of $14.5 \mathrm{~km}$, runs from Parking Lot A on the outskirts of the village of Iwkowa to the village itself. Route no. 2 from Iwkowa through Połom Mały, Porabka Iwkowska to the village of Drużków Pusty, the surveyed section is $8.5 \mathrm{~km}$ long. Route no. 3, $6 \mathrm{~km}$ long, leads from the village of Drużków Pusty to the village of Dobrociesz. Route no. $4,8 \mathrm{~km}$ long, was marked between the villages of Dobrociesz and Wojakowa.

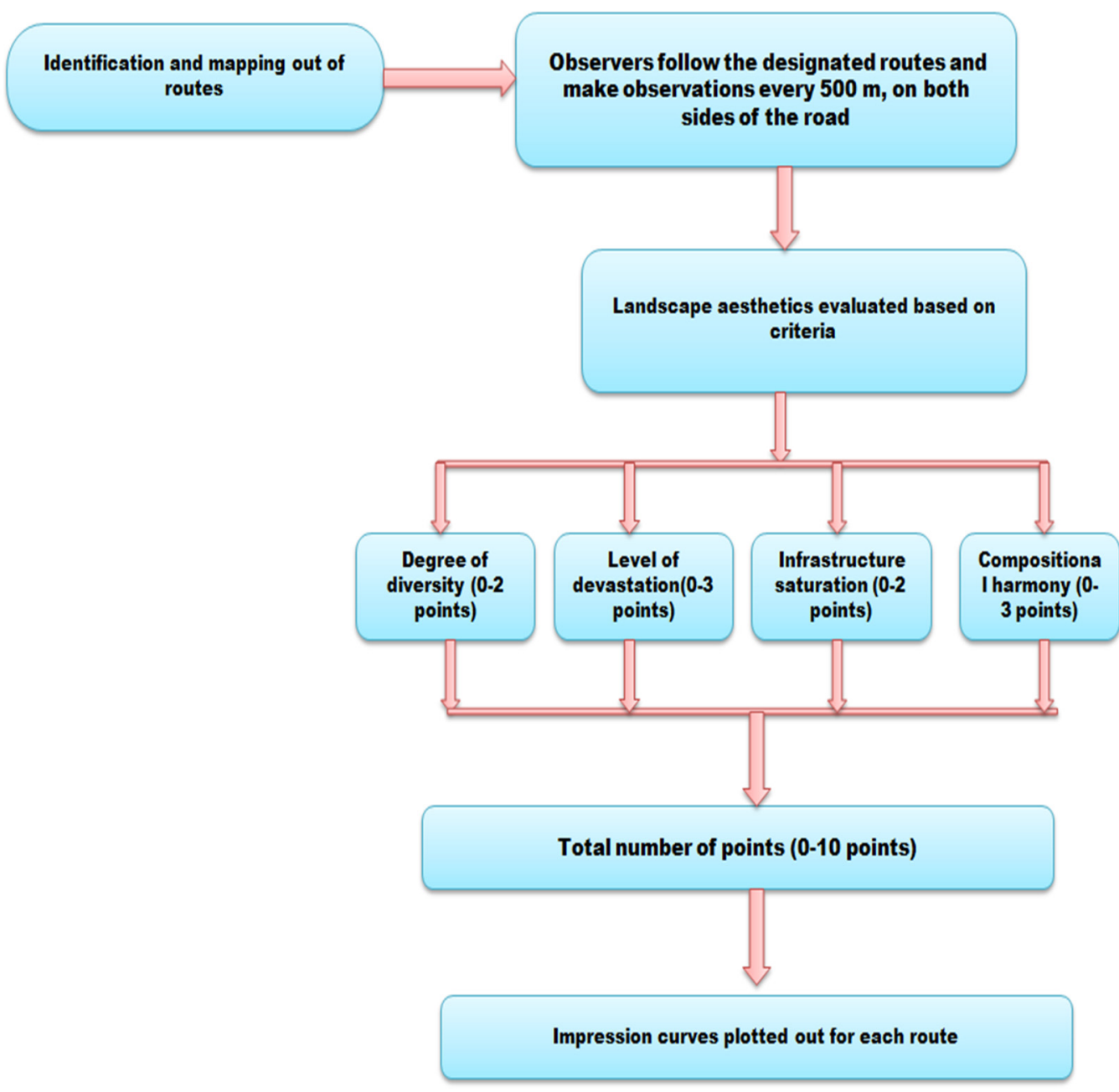

Figure 3. Flow-chart illustrating the application of Wejchert's $[27,28,30]$ impression curve method.

Along each of these routes, landscape aesthetics were assessed approx. every $500 \mathrm{~m}$, separately for both sides of the road, according to the scoring system described above (Table 4). When the points for all categories were added together, the site's final score was obtained. Based on these, curves were plotted separately for the left and right sides. In addition, two cut-off values were marked on the graphs, at 4 and 7 points. Below 4 points, the examined site is deemed to require action aimed at improvement of aesthetic values to a great extent. In the range between 4 and 7 points, intervention is considered required to a moderate degree. In contrast, sites scoring above 7 require no intervention.

To compare the analyzed communes of Brzeski County, and to highlight the statistically significant differences between them in the context of selected valorization scores, an analysis of variance (ANOVA) of quantitative variables was applied (the distributions of the examined variables were first checked using Shapiro-Wilk tests). A significance level of $p<0.05$ was adopted. A cluster analysis was performed, where the explanatory variables were standardized values of valorization scores (Tables 1-3), and the degree of similarity was determined by the Euclidean distance. All statistical analyses were performed using Statistica v.13.0. 
Overall, the research procedures we followed in this study are outlined in two flowcharts in Figures 2 and 3.

\section{Results}

\subsection{Tourism Attractiveness Assessment Using Gołembski's Index}

The results of this analysis of the attractiveness of the seven communes making up Brzeski County in terms of tourism and recreation, using Gołembski's [15] multivariate comparative analysis method, are summed up in Figure 4 (attractiveness to tourists) and Figure 5 (attractiveness to investors).

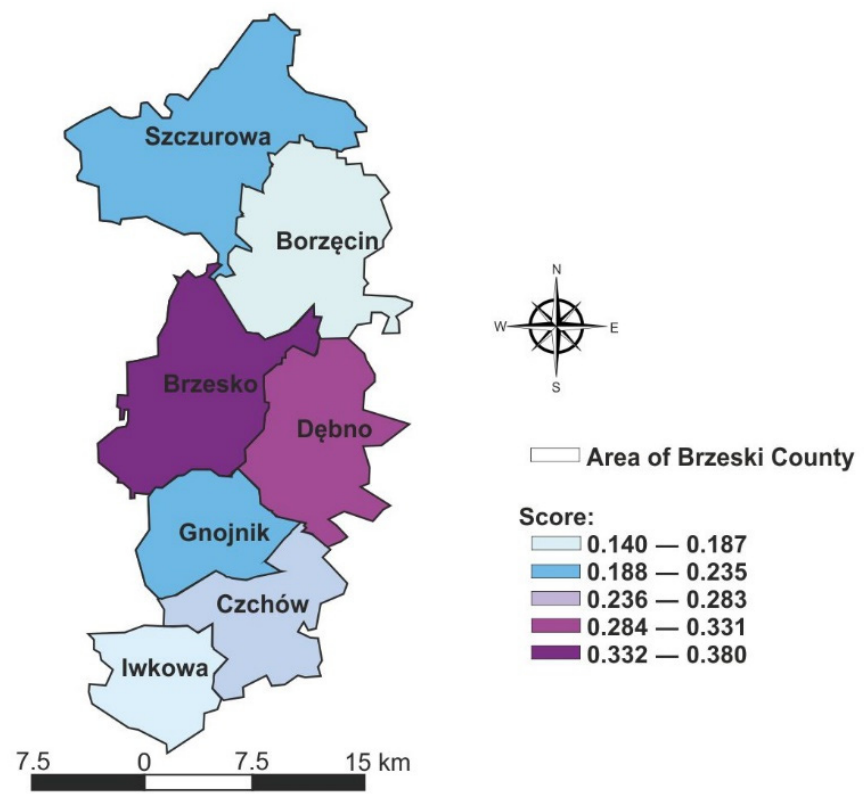

Figure 4. The communes' composite scores in terms of attractiveness for tourists.

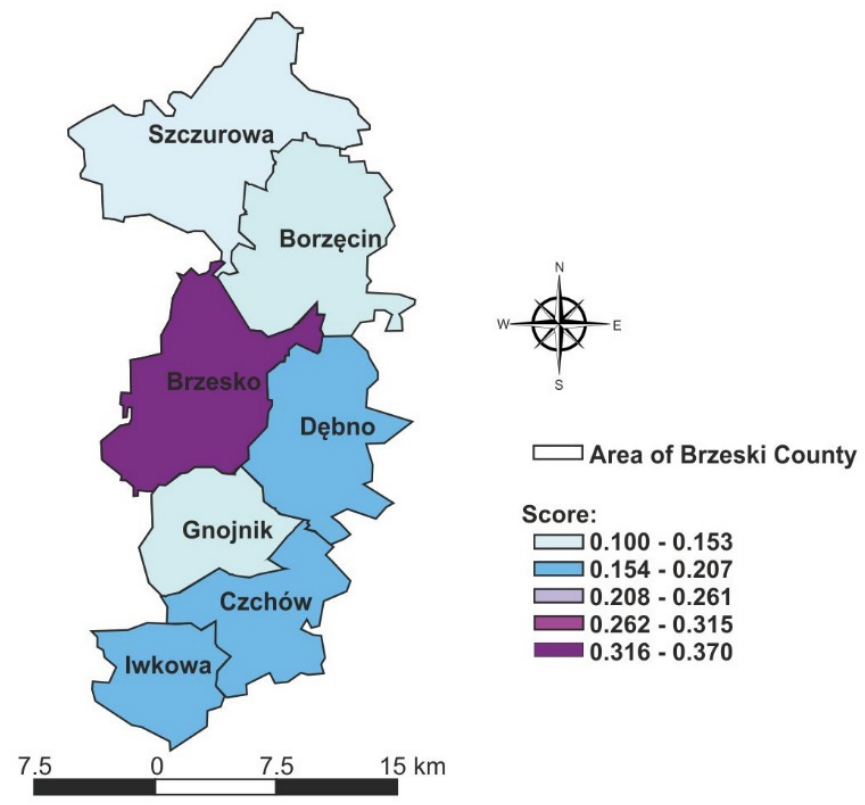

Figure 5. The communes' composite scores in terms of attractiveness for investors.

\subsubsection{Assessment of Attractiveness for Tourists}

Brzesko Commune turned out to be the most attractive in terms of tourism. The tourist attractiveness score for this commune (at 0.38 ) is markedly higher than for the remaining 
communes. Commune fared slightly worse, with a score of 0.32. Czchów Commune also performed quite well in comparison with the communes in Brzeski County (0.26). Fourth place was taken by Szczurowa Commune (0.20), followed by the communes of Gnojnik (0.19) and Borzecin (0.16). Iwkowa Commune had the worst score (0.14). The reason for this is the small number of valuable and historic sites in the commune and the poor value of its environmental protection scores. Summarizing the tourist attractiveness section, the three most important communes in the country were the Brzesko, Dębno and Czchów Communes (Figure 4).

\subsubsection{Assessment of Attractiveness for Investors}

Brzesko Commune was the most attractive in terms of investment (0.37), scoring almost four times higher than in the commune with the lowest value. Brzesko Commune had the highest values in the three sections comprising attractiveness for investors. Czchów Commune was second (0.19), closely followed by Iwkowa (0.18). The lowest value was recorded in Borzecin Commune (0.10) (Figure 5).

\subsubsection{Synthetic Measure of the General Conditions for Tourism Development}

The analysis of variance (ANOVA) showed statistically significant differentiation between the communes in terms of the conditions they offer for the development of tourism $(\mathrm{F}=8.46, p<0.0001$, Figure 6).

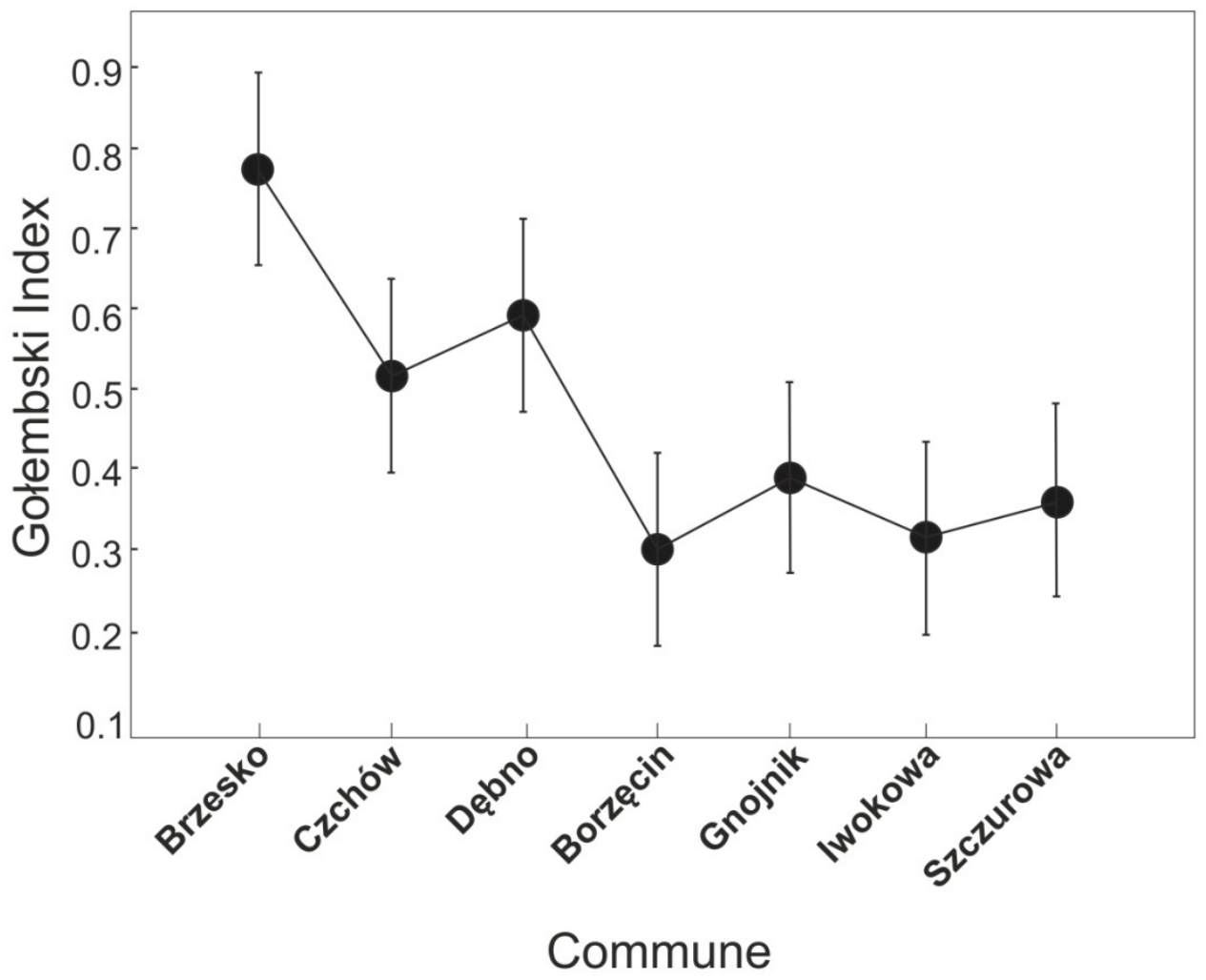

Figure 6. Mean values $\pm \mathrm{SD}$ of Gołembski index for studied communes.

The commune found to have the overall conditions most conducive to the development of tourism was the urban-rural commune of Brzesko (0.75). This commune ranked first in the domain of tourist attractiveness and in the domain of attractiveness for investors. Second place overall was taken by Debno Commune (0.48), which was in second place in the domain of attractiveness to tourists and third place in the domain of attractiveness to investors, losing second place by a small margin to Czchów Commune. Third place overall was taken by Czchów Commune (0.45). It was closely followed by Gnojnik Commune, with a score of 0.34 and in fifth place by Szczurowa Commune (0.33). Right behind that 
was the Commune of Iwkowa with a result of 0.32 . The worst overall conditions for the development of tourism were found to be present in Borzecin Commune, where the value of the synthetic index was 0.26 . This poor standing was occasioned by the small number of heritage sites, poorly developed accommodation and catering facilities, and poor environmental protection and condition (Figure 7).

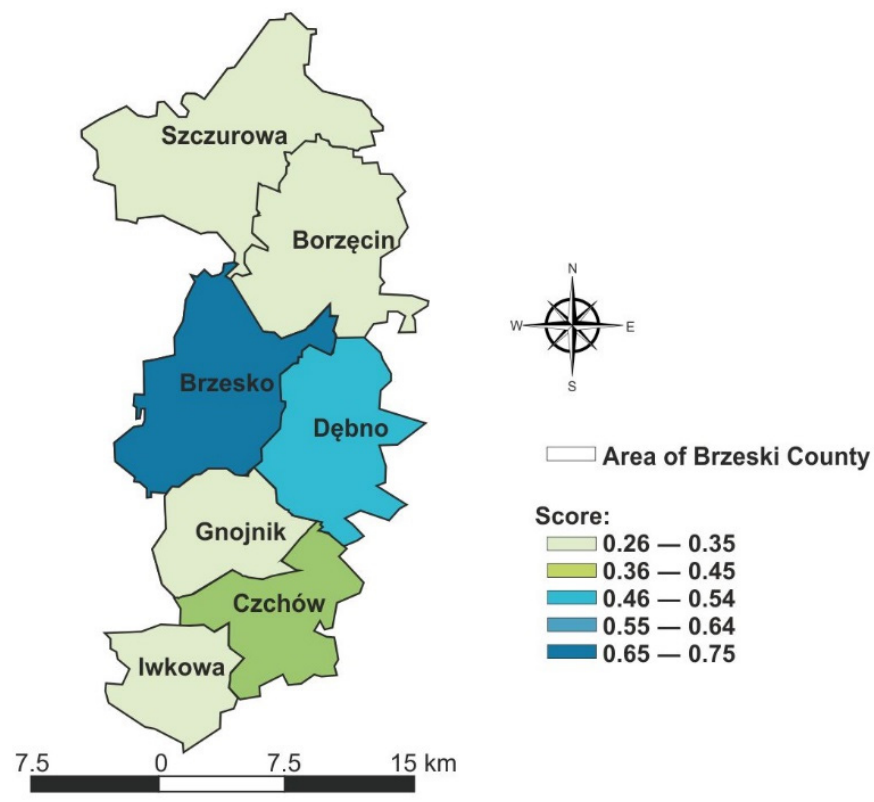

Figure 7. The communes' overall composite score in terms of general conditions conducive to the development of tourism.

\subsection{Aesthetic Landscape Assessments Using Wejchert's Impression Curve Method}

The landscape assessment using Wejchert's impression curve method was conducted for the two most diverse communes for which the cluster analysis showed the largest distances. As the largest Euclidean distance, 1.63, was recorded for the Communes of Brzesko and Iwkowa (Figure 8), they were selected for analysis.

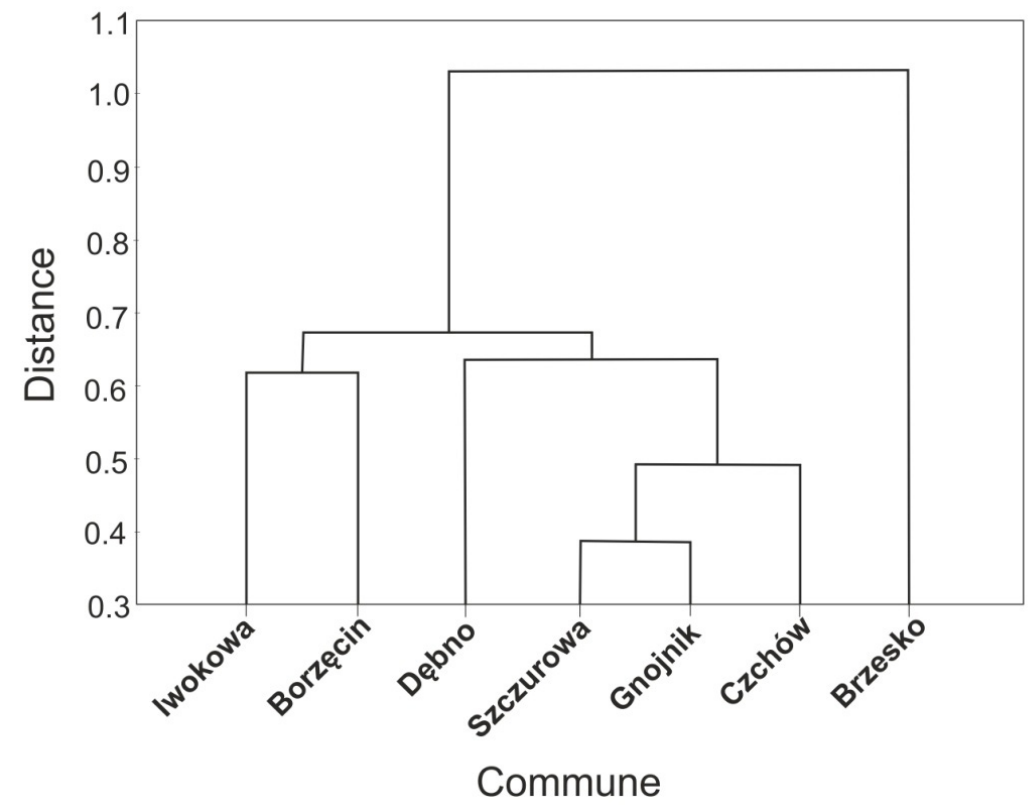

Figure 8. Dendrogram of dissimilarity of Euclidean distance between study communes. 


\section{Brzesko Commune}

Route 1: Jasien-Jadowniki-Sterkowiec-Wokowice. The route has a total length of about $10 \mathrm{~km}$. The landscape rating for this section ranges from 1 point to 9 points. Unfortunately, there are only a few places that scored above 7 points (as areas that do not require intervention) (Figure 9). Most of the route requires moderate (scores between 4 and 7 points) and high aesthetic upgrading (scores below 4 points) [31,49].

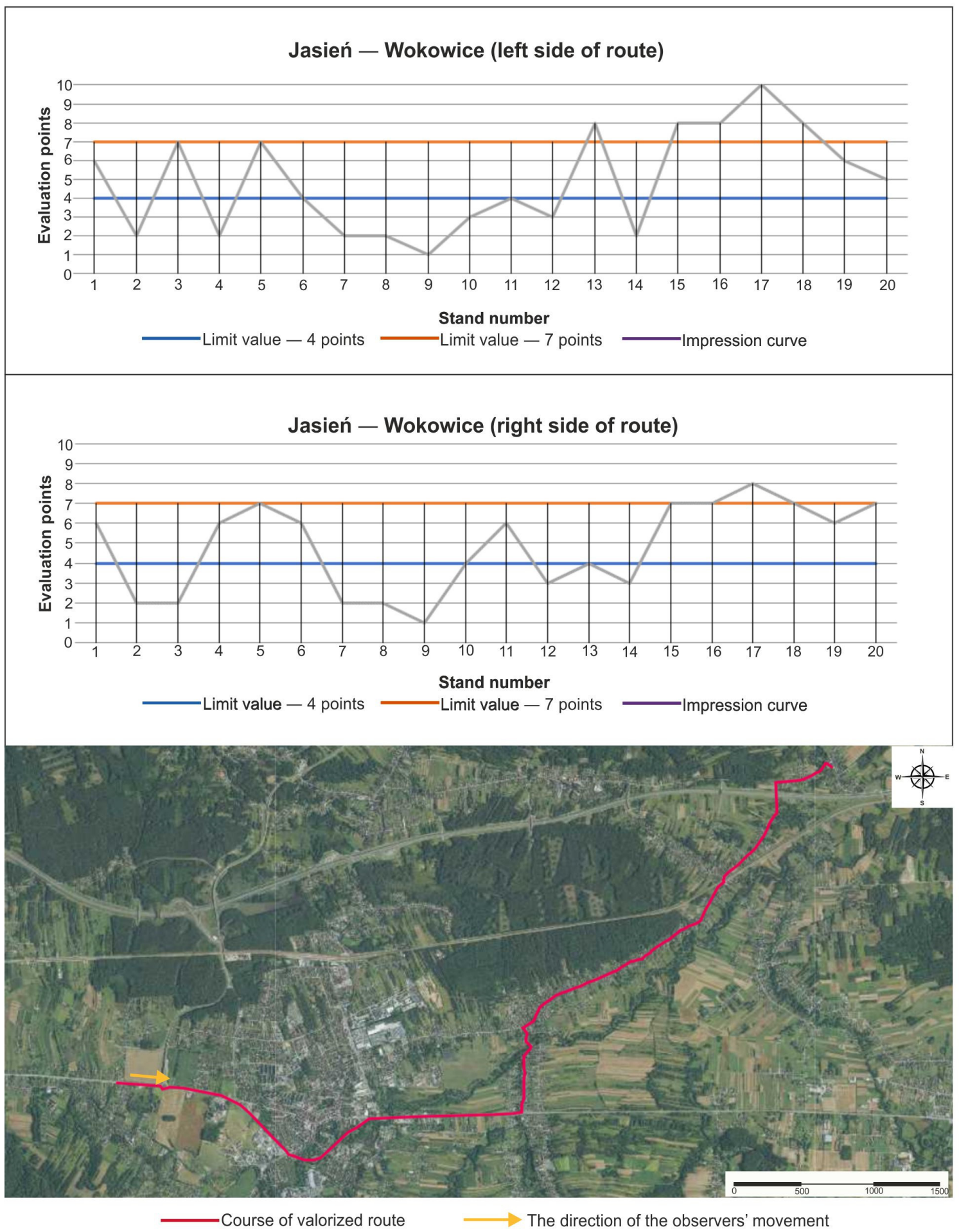

Figure 9. Impression curves for the Jasien-Wokowice route (Commune of Brzesko). 
This is mainly due to the proximity of the railway line and the A4 highway (connecting the border with Germany in Jedrzychowice near Zgorzelec through Legnica, Wrocław, Kraków, Tarnów, Rzeszów and Jarosław to the Korczowa-Krakovets border crossing with Ukraine). The second factor is the dense residential and commercial development of the area. Only in a few places is the landscape diversified by arable fields. However, they are located against the background of road infrastructure (e.g., noise barriers). The low scores are mainly influenced by the saturation of the landscape with infrastructure and the lack of compositional harmony.

Route 2: Wokowice-Szczepanów-Mokrzyska-Bucze-Zalesie. The route is about $13 \mathrm{~km}$ long. The first 4 to $5 \mathrm{~km}$ lead through a monotonous, heavily built-up landscape. The right side is characterized by intense residential development with no landscape vistas. The left side is a view of the nearby A4 highway and associated infrastructure. Further down the route there is significant residential and commercial development. However, its slightly greater distance from road and rail infrastructure means that most of it scores above 4 (with only one site on either side scoring just 1). In this landscape, too, there are few areas that scored the maximum number of points-10 (Figure 10). Nevertheless, most of the area is characterized by high infrastructure saturation, a lack of harmony and monotony. This results in the aesthetics of the area needing a moderate level of improvement.

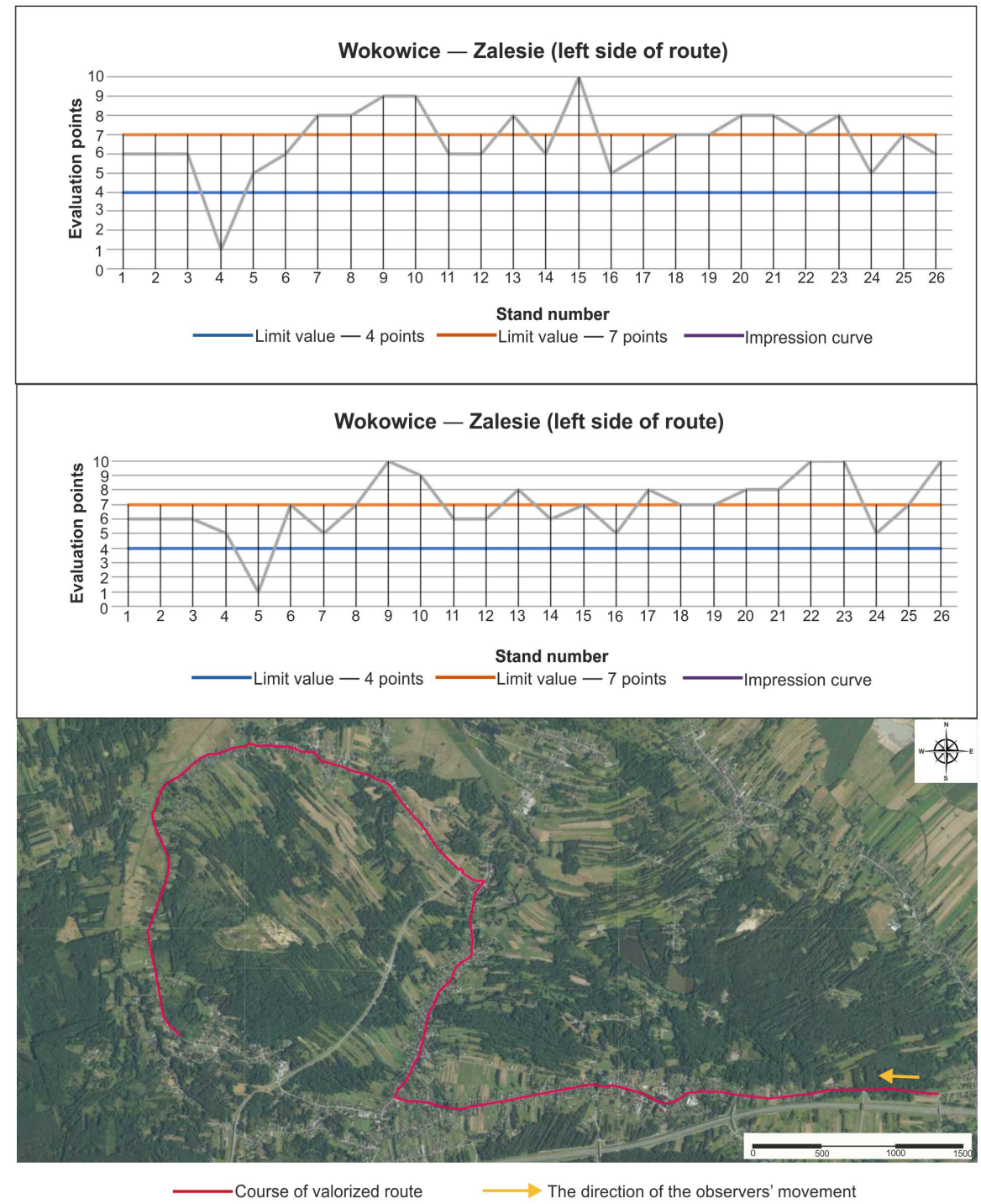

Figure 10. Impression curves of for the Wokowice-Zalesie route (Commune of Brzesko). 
Route 3: Zalesie-Brzesko-Okocim. The route is about $7.5 \mathrm{~km}$ long. This route runs through areas characterized by intensive transport development and the built-up area of the town of Brzesko. Ratings for the aesthetics and harmony of this area range between 2 and 10 points (Figure 11). Unfortunately, both on the left and on the right, most of the route was classified as needing moderate intervention and, in places, high intervention. Initially, the route passes through harmonious areas with sparse rural buildings. Another section crosses the highway and a railway line, which significantly reduces the landscape and natural values of the area. The next section is the intensive development of Brzesko, which mainly consists of low-rise tenement houses with a commercial section. Landscape values are negatively affected by the lack of greenery and a large number of unsightly advertisements. One major downside is the market square which, like many others in small Polish cities and towns, "fell victim" to redevelopment, in a project completed in 2011. Unfortunately, this involved a removal of greenery, covering the whole area with paving, and placing a lighted fountain in the middle. According to the evaluators, this location is one of many points in need of aesthetic improvement.
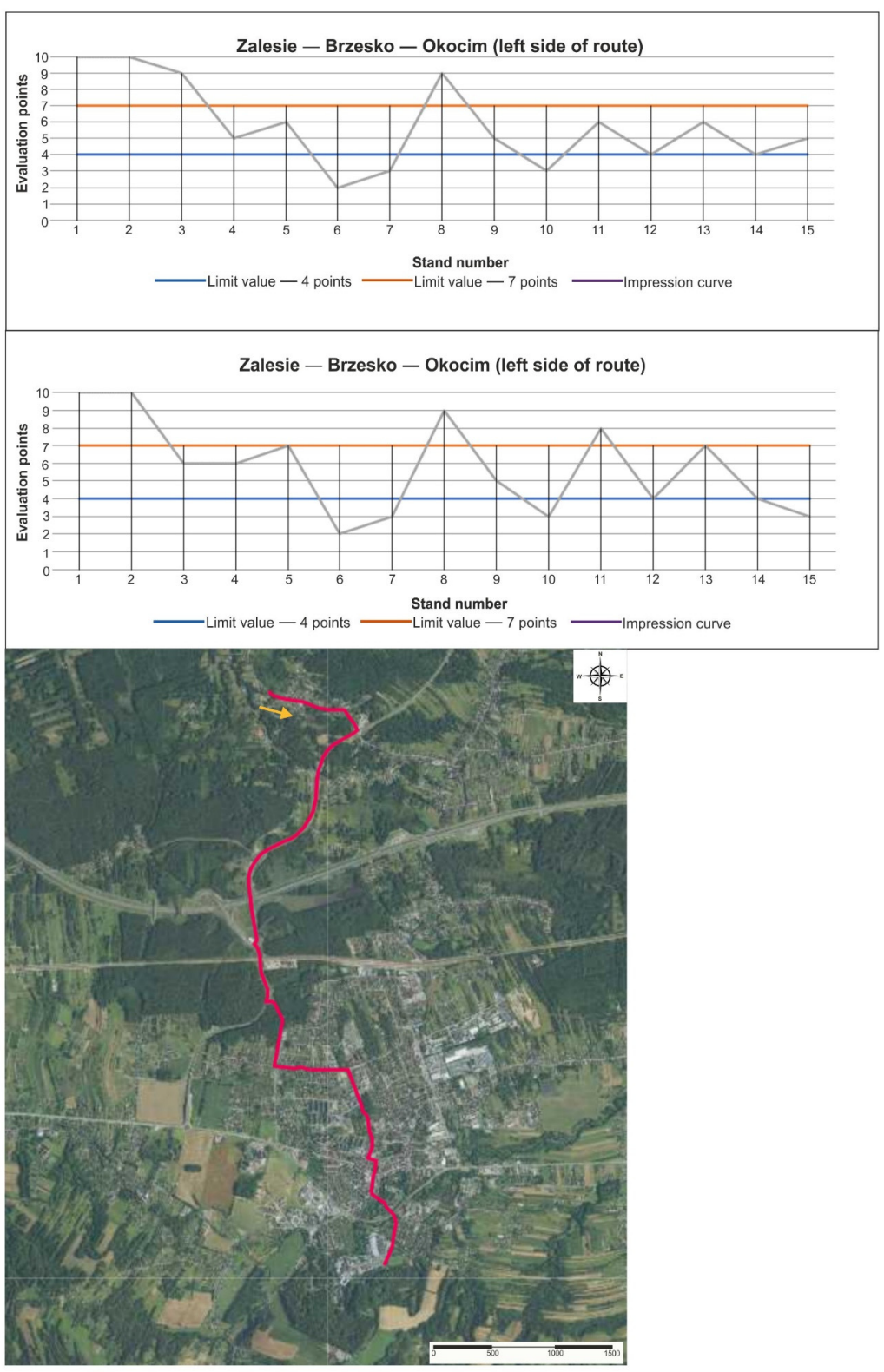

Course of valorized route $\longrightarrow$ The direction of the observers' movement

Figure 11. Impression curves for the Zalesie-Brzesko-Okocim route (Commune of Brzesko). 
Route 4: Okocim-Poreba Spytkowska. The route is about $7.5 \mathrm{~km}$ long. The section of the route between Okocim and Poreba Spytkowska is significantly different from the other three routes. This is a typically agricultural area with sparse development, farmland and open views. It is the highest rated by observers. On both sides, the scores range between 6-10 points (Figure 12). In just two cases on the left and one on the right, the value was 6 points. Much of the route was rated 10 points-these are areas of harmonious rural development. In a few of the lower-ranked sites, the infrastructure was more saturated, not always blending in well with the relief and vegetation.

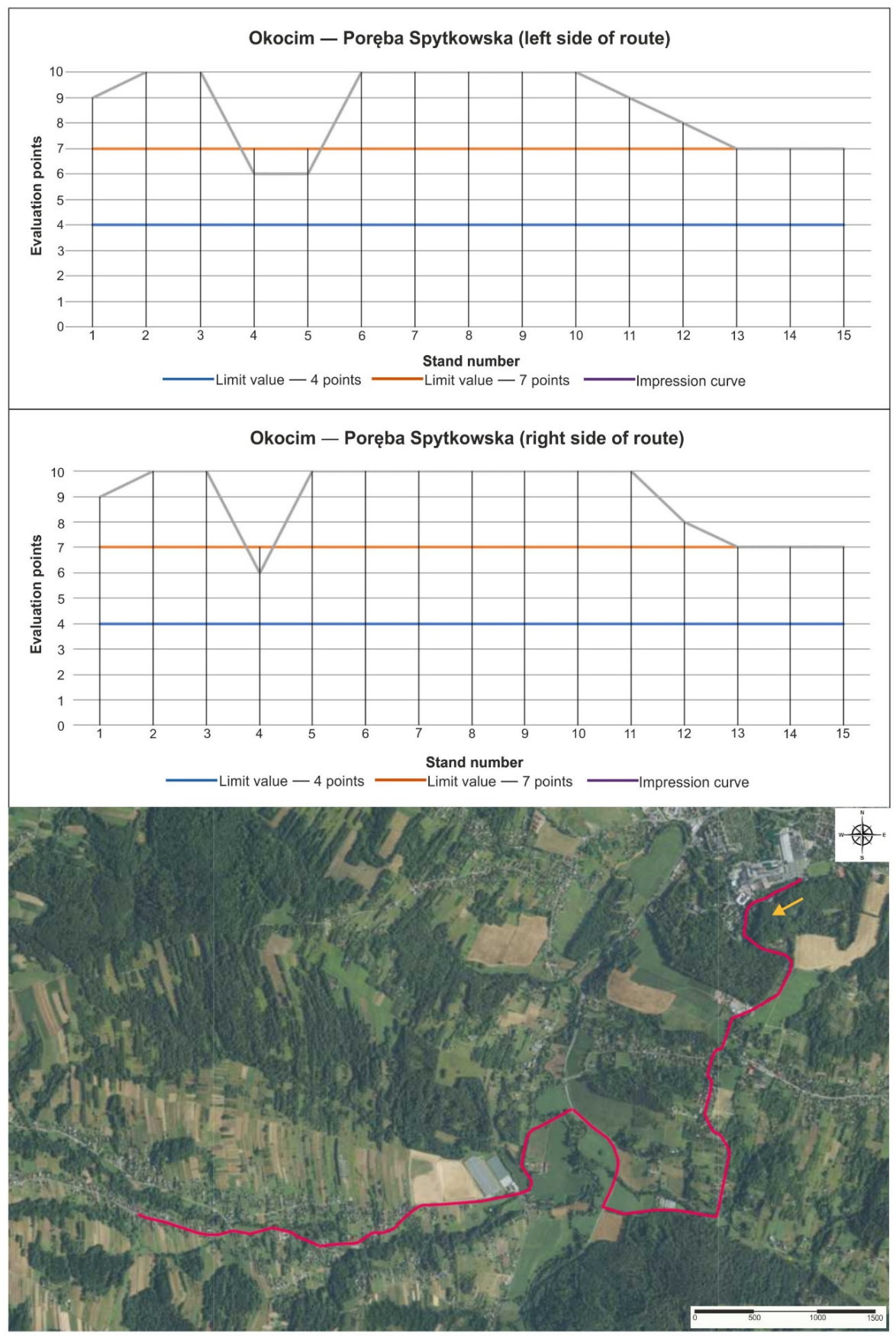

$\longrightarrow$ Course of valorized route $\longrightarrow$ The direction of the observers' movement

Figure 12. Impression curves for the Okocim—Poręba Spytkowska route (Commune of Brzesko). Commune of Iwkowa. 
Route 1: Parking lot A (Iwkowa) - Iwkowa. The route is about $14.5 \mathrm{~km}$ long. The section under assessment runs through agricultural areas. Farm buildings are arranged in a harmonious way, the density is low, well integrated into the hilly landscape with numerous landscape vistas. The landscape of Iwkowa has typical rural features with a mosaic of arable fields, forests and farm buildings surrounded by orchards. Amongst the village buildings one can see old wooden houses preserved in the typical Beskid rural style. Sporadically, in the central part of the village, the buildings are denser, which slightly lowers the assessment. On both the left and right sides of the route, the landscape was rated between 6 and 10 points (Figure 13). However, it is worth noting that only one place along the entire route was rated at 6 points. The average score for the left side is 8.8 points, and for the right 8.2. Given the incidental score of less than 7, this area does not require intervention to improve landscape aesthetics (Figure 13).
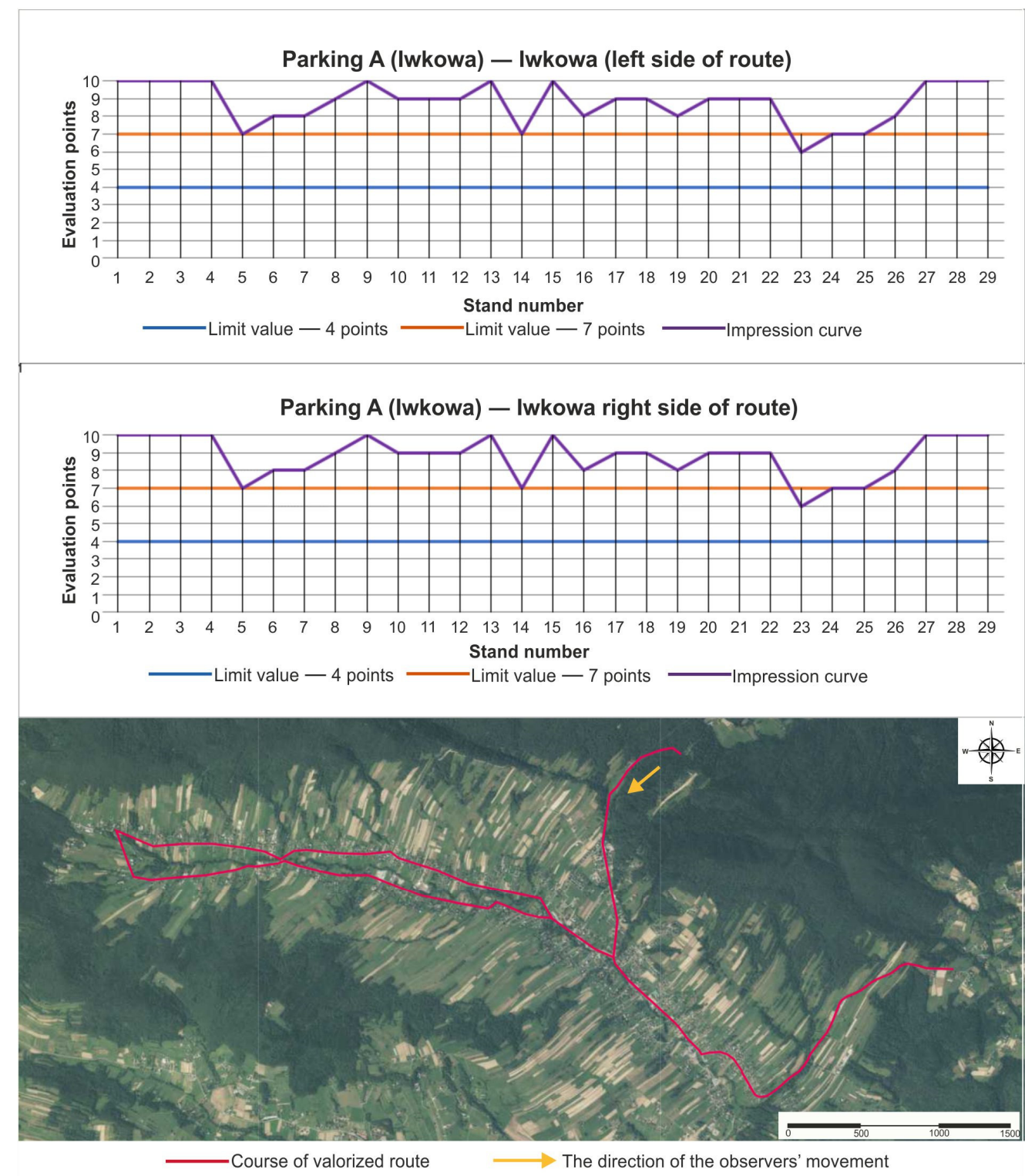

Figure 13. Impression curves for the Parking A (Iwkowa)-Iwkowa route (Iwkowa Commune).

Route 2: Iwkowa-Połom Mały-Porąbka Iwkowska-Drużków Pusty. The route is about $8.5 \mathrm{~km}$ long. It leads through very picturesque terrain with open views of the surrounding hills in the foreground and a wider view of the peaks of the Island Beskid Mountains and the Rożnowskie Foothills. Development is highly dispersed here and its 
functions are mixed. In this structure, we have a lot of arable fields, forests, orchards and meadows. The route averaged 8.6 points on the left and 8.5 points on the right. Scoring ranged from as little as 5 points (one spot on each side) to 10 points. On both sides, only in two places was the landscape evaluated below the 7-point limit (Figure 14). This is an area belonging to the two villages of Drużków Pusty and Porabka Iwkowskain contrast to the remaining area, it has been quite heavily invested in. In addition to residential development, there is also service and production infrastructure. As a result, there are large advertisements and buildings of an industrial nature which disfigure the landscape. Moving further towards the village of Dobrociesz, there are once again sparse farm buildings and a picturesque mosaic of arable fields, meadows and small orchards. Aesthetic values are strongly influenced by small-scale arable fields, which are quite characteristic of the mountainous and submontane region.

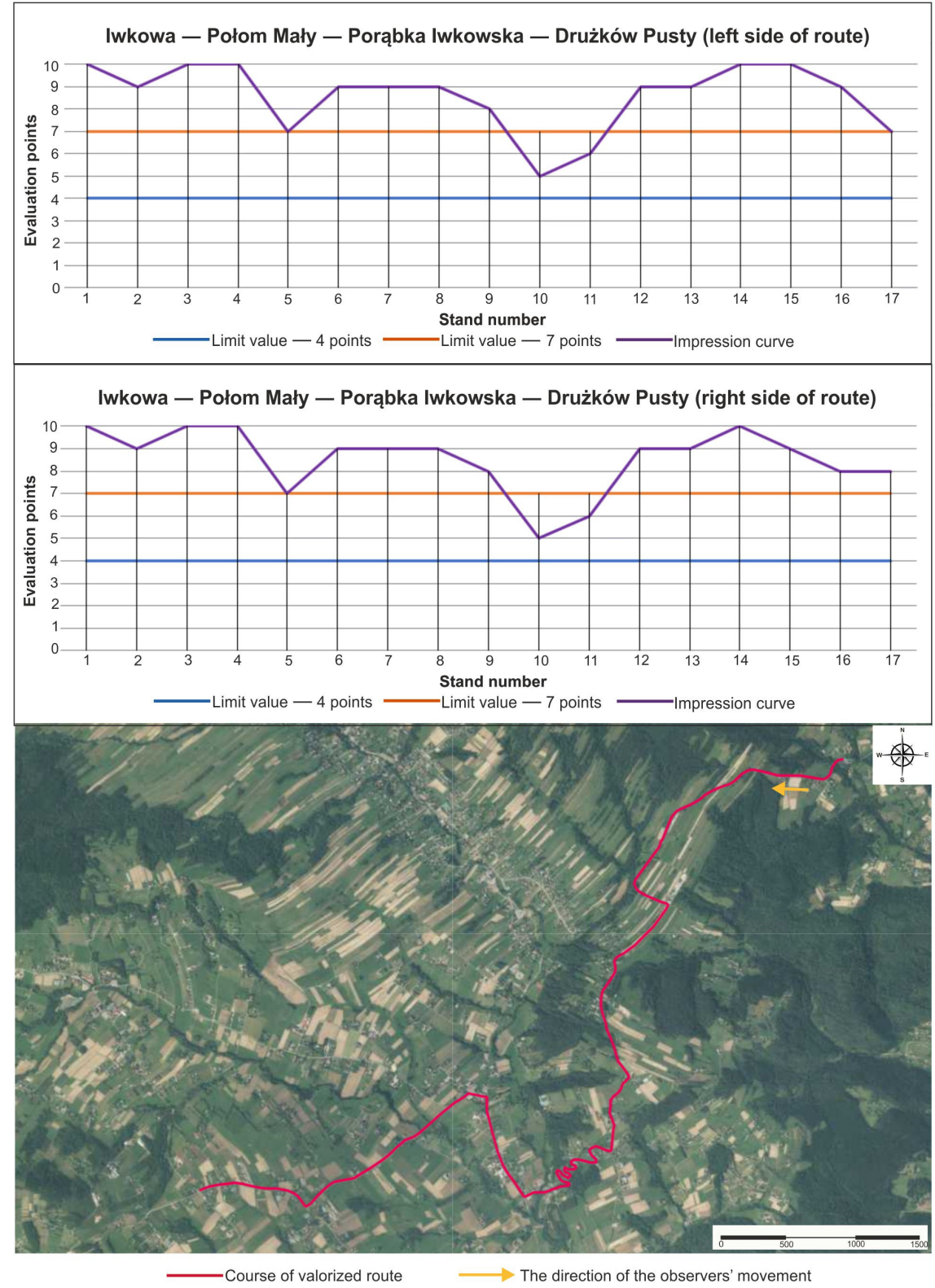

Figure 14. Impression curves for the Iwkowa-Połom Mały-Porabka Iwkowska-Drużków Pusty route (Commune of Iwkowa).

Route 3: Drużków Pusty-Dobrociesz. The route is about $6 \mathrm{~km}$ long. The evaluated section is located in the southern part of the commune. With the exception of one site 
on the left side of the route, it was rated above 7 , meaning it does not require changes to improve landscape aesthetics. On the left side, there was only one point rated at 6 points; the lower score was influenced by the buildings of a construction company located there together with a machine park. The average score for the left side is 8.6 points, while the for the right it is 9.0 points (Figure 15). As with the earlier section, there are sparse agricultural buildings and open views of farmland and meadows. The landscape is diversified by quite numerous mid-field and roadside trees. The final section within the village of Dobrociesz, lying somewhat higher at an altitude of about $400 \mathrm{~m}$ above sea level, allows visitors to observe the beautiful open landscape of the Łososina Valley and the neighboring hills, as well as a further view of the Island Beskid peaks. This section, on both sides of the road, received the highest score of 10 points.
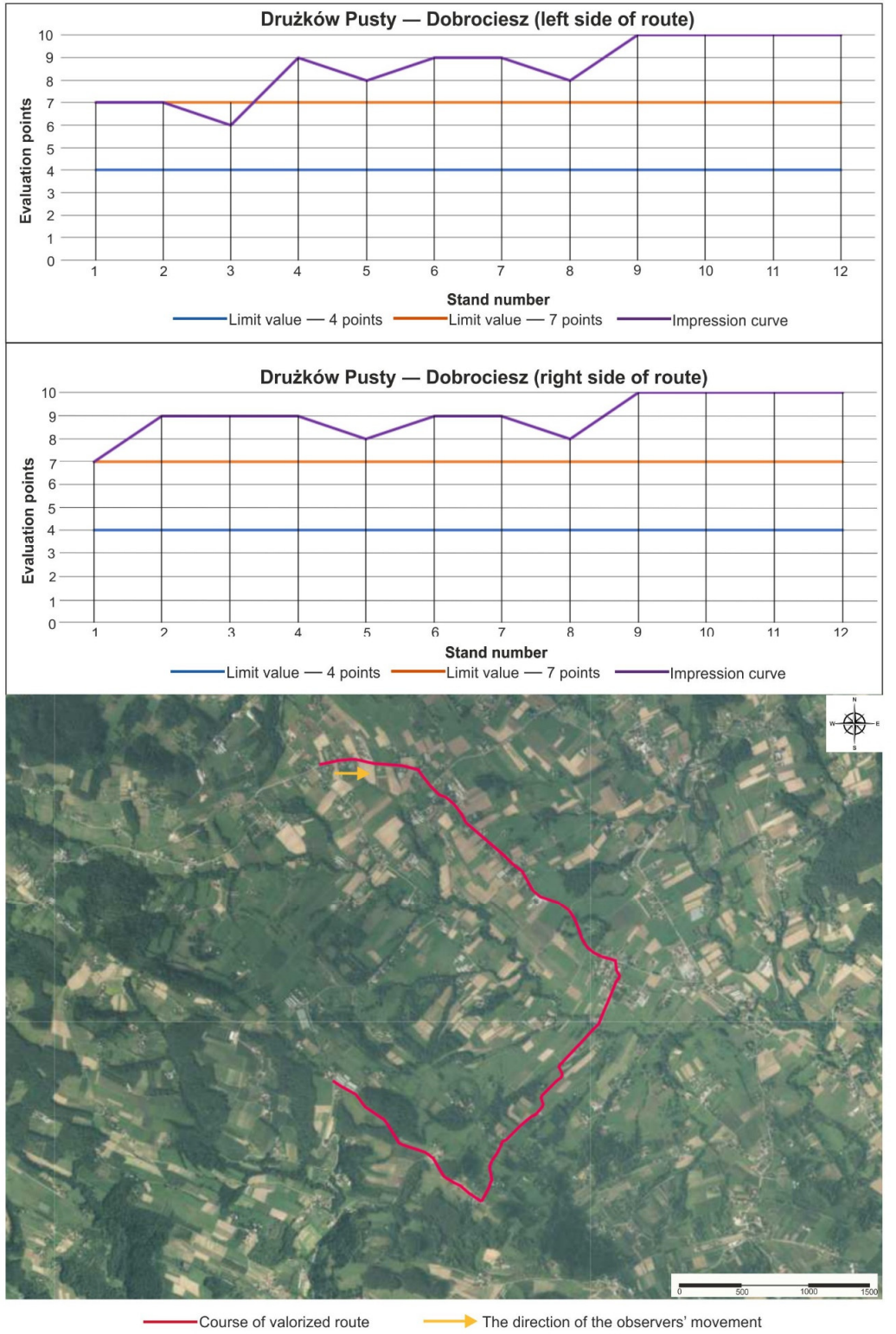

Figure 15. Impression curves for the Drużków Pusty-Dobrociesz route (Iwkowa Commune).

Route 4: Dobrociesz-Wojakowa. This section is about $8 \mathrm{~km}$ long. The route on both sides was rated the highest, with an average of 9.3 points on the left and 9.1 points on the right. The lowest score received on this section was 8 points (Figure 16). The first part of this area is almost completely devoid of buildings, while the later part is characterized by very sparse buildings. As in Route 3, the focus is on open landscape here. The view to 
the left is particularly noteworthy. In the foreground there are the low peaks of the Island Beskids, including Kopiec (585 m), Kobyła (605 m) and Jastrzab (565 m). When visibility is good, it is possible to observe the higher and somewhat more distant peaks of the Island Beskids. Forests and orchards with a small share of arable fields are increasingly frequent in the structure. Meadows and farmland appear roughly from kilometer 4 onwards, while the infrastructure is still very sparse here. Very small and irregularly shaped arable fields add an interesting touch. The final section is characterized by a larger (but still small) share of farms. The integration of rural areas into lower-lying areas and the slopes of the surrounding hills left wooded are worthy of high marks.
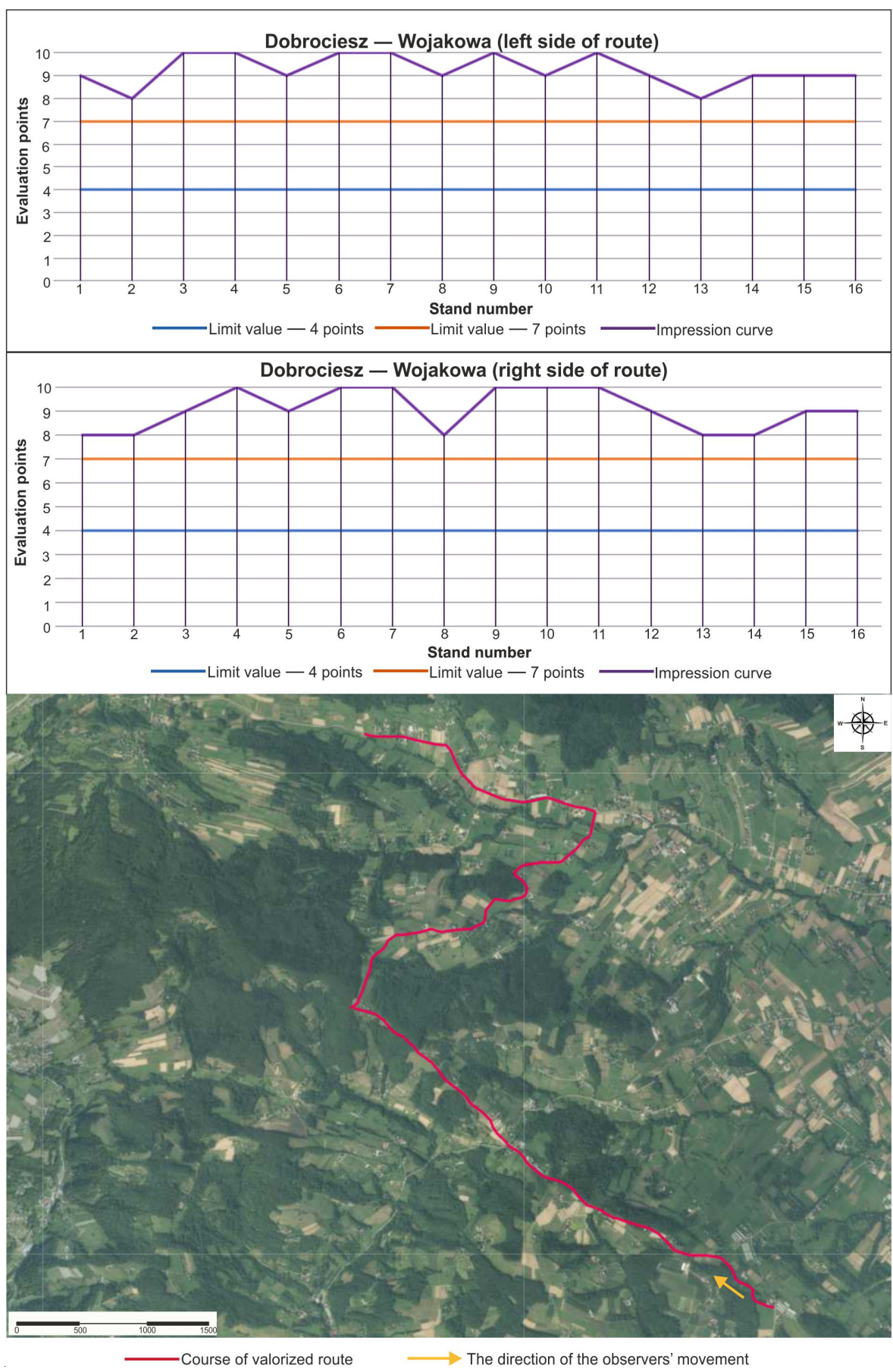

Figure 16. Impression curves for the Dobrociesz-Wojakowa route (Iwkowa Commune). 
Analyzing the results obtained and the average number of points given for individual routes in both communes (Table 5), Iwkowa Commune turns out to be much more attractive in terms of landscape aesthetics (ANOVA results for the left side: $\mathrm{F}=56.14, p<0.0001$; ANOVA results for the right side: $\mathrm{F}=41.89, p<0.0001$ and ANOVA: $\mathrm{F}=54.56, p<0.0001$ (Figure 17)).

Table 5. Average scores using Wejchert's impression curve method for the Communes of Iwkowa and Brzesko.

\begin{tabular}{ccccc}
\hline & Iwkowa & & \multicolumn{2}{c}{ Brzesko } \\
\hline Left & Right & Left & Right \\
\hline 8.8 & 8.2 & 4.9 & 4.8 \\
8.6 & 8.5 & 6.7 & 6.9 \\
8.6 & 9.0 & 5.8 & 5.8 \\
9.3 & 9.1 & 8.6 & 8.9 \\
\hline
\end{tabular}

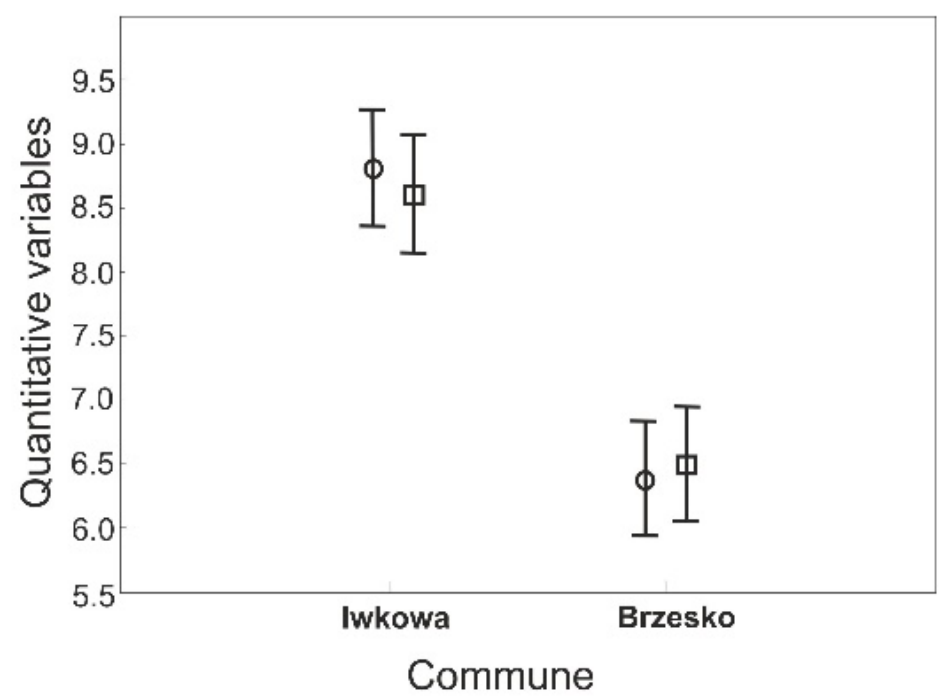

Figure 17. Mean values \pm SD of quantitative variables for Iwkowa and Brzesko commune ( $\gamma$-right side, o-left side).

\section{Discussion}

One of the strategic operational objectives in Brzesko County's Development Strategy for 2014-2020 is creating attractive infrastructure for tourism and recreation. The county authorities have a vision of a well-developed tourism industry, with ideas including developing cycle paths and tourist trails, creating sites attractive to tourists and designing a new, comprehensive tourism strategy. The county authorities have focused on communes with the greatest potential for development: Czchów and Dębno. These decisions can be seen as corroborated by our study conducted using Gołembski's [15] synthetic index, which indeed reveals these two communes as potentially some of the most attractive to tourists. Communes in the north and south of the county show poor results, as has been noted both in our study using multivariate analysis and by local officials themselves in their County Development Strategy, who feel obliged to work with local commune authorities to jointly develop the severely lacking tourist infrastructure. A few years ago, a poll was conducted among local residents for the County Development Strategy. The respondents regularly noted the lack of tourist trails and cycle paths and an insufficient number of sports and recreation centers and children's playgrounds. They also noted the underdeveloped sewage system in the county, as confirmed by the major variation in the environmental indicator, with Iwkowa and Borzecin communes still lacking sewage systems. 
Pukowiec and Kurda's [50] study of communes in the Lubliniecki County in Poland's Silesian Voivodeship also used similar synthetic scores. The factors they considered were split into three groups: natural and cultural features, tourist infrastructure and transport accessibility. Their calculations showed the commune with the highest value of the synthetic indicator for attractiveness to tourists to be the Lubliniec Commune (0.69), with a highly developed service infrastructure and the most highly developed food-service industry in Lubliniecki County. The commune with the second highest synthetic indicator was Koszęcin (0.57), which scored the highest result in terms of meadows and pastures, as well as accommodation base. Both of these communes from the Lubliniecki County are comparable to the Brzesko Commune, which achieved the highest results in all indicators which affect the development of tourism.

Tokarska-Osyczka and Iszkuło [51] argue that the most important natural features affecting aesthetics are forests, lakes and type of landscape. The authors also consider industrial centers as having a negative impact on natural features. Their investigation of cultural features mainly focused on museums, registers of monuments and sites with the highest numbers of cultural venues. Communes in the Miedzychodzko-Sierakowskie Lakeland by the Warta River were assessed using point valuation and the features outlined above. Their results revealed that the region is attractive in terms of tourism and its development. The extensive forest cover, high number of rivers and streams and low degree of industrial contamination make the region attractive in terms of natural features. Międzychód Commune achieved the highest score in the study. In terms of cultural values, communes in the lakeland show poorer results. None of the communes achieve results which would place them in the first class. Chrzypsko Wielkie was the only commune to be assigned to the third class, with all remaining communes falling into the second class. In summary, Międzychód Commune is the most attractive to tourists in terms of its natural and cultural features.

Połucha and Marks [52] take a similar view on features affecting the development of tourism. Their research noted the same features as were highlighted by Tokarska-Osyczko and Iszkuło [51,53]; however, they believe that transport and capacity of the tourist service industry also play an important role. The authors present an assessment of natural and cultural features of the Reszel Commune, also using point valuation. Results revealed that the commune has tourism potential, although it is not being exploited by the local authorities or residents. The study indicated that alongside existing tourist resources, the region has areas with potential for development; the introduction of cycle paths and tourist trails would have a positive impact on tourism in the region.

Brzeski County faces similar problems to those reported for Reszel Commune; however, in spite of slow development of tourism and recreation, the country is seeing a positive trend. A viewing tower was opened on Szpilówka Hill in Iwkowa Commune in 2018; the structure aims to make the region more attractive and to draw tourists from neighboring communes and counties. A shopping mall "El Galeria" is under construction in Brzesko with an adjacent bus station, which was previously lacking in the county. The mall aims to attract new companies, provide employment and improve the town's attractiveness, while the bus station will allow potential tourists to travel to Brzesko Commune. The station will provide transport links throughout communes in the county.

Evaluating the positive qualities of landscapes is an important element of spatial planning in regions with an attractive natural environment and with high tourist potential. Its aim to provide environmental, aesthetic and cultural protection [53]. The beauty of the landscape is just one of the factors affecting tourist development of a given region, and its objective assessment is extremely difficult [54-57]. However, it is widely assumed that most people perceive certain phenomena in a similar way, frequently due to cultural and social conditioning and similar traditions and value systems. Contemporary society places high value on natural landscapes [33,49]. Another important factor is visual quality, which is inseparably linked with healthy ecosystems. Krzymowska-Kostrowicka [58] argued that the perceptions of landscape quality have a major impact on decisions made by tourists 
(63.7\%). Scolozzi et al. [59] reported that despite the economic crisis, Alpine regions are increasingly appreciated by tourists interested in the natural world. They list aesthetics and picturesque quality alongside factors such as spending time in the fresh air, quietness and historic and cultural factors.

Beautiful views and extensive panoramas have a major impact on how people select the destination and form of leisure. The most popular and frequently visited landscapes are visually diverse with interesting natural terrain, waterways and layout of fields, meadows and forests [60-62]. The beauty of the environment has a positive impact on our comfort and wellbeing [22], as well as being an important element of a given area's tourism and recreation potential $[63,64]$. Its visual attractiveness forms the basis of planning decisions, for example by marking regions for tourism or recreation [28,64,65].

One of the many ways of evaluating the subjective visual impressions of landscapes is Wejchert's impression curve [30]. It is used to identify attractive locations and those which require intervention in order to improve their aesthetic values. Although originally developed for urban spaces [29], it has been adapted and used to evaluate rural areas [29]. The method has been used by Mordaw [66] to identify attractive locations along the Piotrkowska Street pedestrian area in Łódź, concluding that the method is applicable in the assessment of linear urban spaces. He also confirmed Wejchert's assertion that casting a particular place to memory fosters a specific attitude towards it and aids its critical assessment. Adamiec [65], in turn, used the impression curve to evaluate natural and landscape features of Lublin's river valleys, with results indicating that the greatest threat to river valleys is excessive urbanization and also individual profits and gains being placed above the unique beauty of these regions. Similar problems can be found in Brzesko Commune, studied herein, where the excessive infrastructure and inconsistent composition have a negative effect on how the region is perceived.

Senetra [62] stresses the importance of forests as an element enhancing landscapes. While dense, large forests are seen as less attractive due to their visual monotony and lack of perspective, in general forest regions are assessed as moderately and highly attractive. Closely built-up areas are described as significantly less attractive. In our study, Iwkowa Commune scored highly on the aesthetic scale, largely due to the high number of forests many of which grow on hills, making the landscape more varied. Comparing our results to the assessment of the visual attractiveness of the Narew National Park conducted by Malinowska [64], we can conclude that dominant and subdominant elements, both natural and man-made, play a significantly more important role in lowland regions.

Zajac et al. [26] studied the village of Panieńszczyzna in Poland's Lublin Voivodship and reported that it faces similar problems to those we found for Brzesko Commune, including chaotic, disordered clusters of buildings and poor road infrastructure, including acoustic screens.

The majority of researchers stress the importance of open vistas, varied mosaics of fields, meadows, orchards and forests and orderly buildings preserving details of local style $[26,49,65,67]$. Factors bringing down the perceived value of landscapes include large clusters of buildings, in particular ones dilapidated or mismatched in terms of architectural and cultural styles, loss of agricultural function, low forest cover and mundane terrain lacking any distinctive features. These problems were also noted in our study for Brzesko Commune, which scored poorly in terms of the attractiveness of the landscape.

The planning documents (development strategies) that serve as the basis for official land-use studies and local zoning plans make reference to tourism issues at each administrative level. Generally, tourism objectives are part of the development strategy of a broader area, although some local authorities do prepare a separate, local tourism strategy. Development strategies should take into account the possibilities for synergistically combining tourism with other forms of economic activity: agriculture, health services, medicine, agrotourism, health tourism, or ecotourism. When planning the development of tourism, all stages of development should be taken into account, from assessing the current status of tourism, the existing tourism assets and infrastructure, and the resources that can 
be involved in its further development, to defining the objectives of tourism development and the tasks and undertakings connected with them, to identifying the tools for their implementation, especially financial means and institutional aid (including education and training), and finally also evaluating demand [68].

Tourism as a multifaceted phenomenon leaves its mark not only on the environment itself, but also on the communities that are directly or indirectly connected with the areas of tourist interest. Negative consequences can be mitigated by basing tourism activities on the principles of sustainable tourism development. The basic legal principles of sustainable development in tourism are stipulated in basic documents of Poland and the European Union. Through its legislation, the EU has an indirect influence on the tourist industry; by issuing directives, it imposes an obligation to adjust national legislation to the EU requirements. In accordance with the general idea of sustainable tourism development, local authorities have an important role to play. This is justified in that it is at the commune level that the principles of ecological policy are implemented and realized and direct actions shaping the tourist space are undertaken. In economic practice, one can find a number of activities consistent with the idea of sustainable tourism that are actually being undertaken by tourism enterprises [69-71].

Sustainable tourism aims to promote activities preserving natural features of the given area while causing as little damage as possible to the natural environment and landscape. Scolozzi et al. [59] reports that tourists most commonly note the following threats to the attractiveness of a given region: urbanization, lack of maintenance, congestion, visual and/or acoustic disturbance, pollution, overuse, and traffic. The question remains whether communes with low tourism potential but with attractive natural and landscape features should receive additional financing in order to improve their infrastructure, or whether these regions should be left without intervention or promoted as ones designated for sustainable tourism, sound tourism or ecotourism.

\section{Conclusions}

Our calculations using Gołembski's synthetic index to evaluate the conditions required for the development of tourism suggest that, among the seven communes in Brzeski County, the urban-rural Brzesko Commune has the highest indicator of tourism potential. The commune is the most attractive to tourists and investors, it contains the highest number of historic monuments, it boasts the most extensive accommodation, gastronomic and service sectors, and its budget is the highest in Brzeski County. The main factor driving these indicators is the presence of the town of Brzesko in the commune.

Dębno Commune scored highest in terms of environmental protection and placed second in terms of tourism features, condition of the environment, transport and societal relations. In terms of the Gołembski indexes for separate domains, the commune was found to be the second most attractive to tourists and the third most attractive to investors.

Czchów Commune, in turn, scored quite well on the indexes. It was found to be the third most attractive commune to tourists. This is due to a relatively well-developed accommodation base and gastronomy industry, and a high degree of attractiveness to investors, placing Czchów Commune second in the region.

Lastly, the Borzęcin and Iwkowa communes scored poorly in terms of attractiveness to tourists as gauged by the Gołembski index, mainly due to their lack of a sewage system and the absence of historic sites. Additionally, Iwkowa is only accessible by minor local roads.

Analysis of the Brzesko and Iwkowa communes (the highest-ranking and lowestranking ones) in terms of their physiognomic landscape parameters, however, yielded some intriguing results. Although according to Gołembski's synthetic index Brzesko Commune has a higher tourism potential than Iwkowa Commune, it scored far more poorly in terms of visual attractiveness, as gauged by Wejchert's [32] impression curve. Three of the four routes evaluated scored below 7 points, which means they need intervention to improve their attractiveness. In Iwkowa Commune (with the lowest tourism potential according 
to Gołembski's synthetic index), all four Wejchert impression curves for both directions scored 7 or above, and in one case (in both directions) the average exceeded 9.

These findings illustrate an important point: that the beauty of the landscape in a particular region is not always correlated with the real and potential development of tourism and the attendant infrastructure. This raises the question of whether regions of outstanding natural beauty, which frequently goes hand in hand with environmental values, should be exploited with mass-scale tourism infrastructure. While the development of tourism in most cases improves the social and economic situation of local residents, on the flip side it can create many serious threats to the natural environment and landscape. This can lead to a gradual loss of aesthetic and natural features, which in turn carries negative outcomes for the environment and for locals employed in the tourism industry. In areas of outstanding natural beauty, it is especially important to promote sustainable tourism and educating local residents on the role of the landscape and the natural environment in the local economy.

Given the growing popularity of sustainable tourism and leisure in beautiful, picturesque regions-in lieu of more traditional sightseeing activity or relying on extensive infrastructure-it is important to conduct further studies into aesthetic values of tourist regions. However, it is a point for discussion whether such regions should be heavily invested in and promoted on the wide scale. A further question is whether regions such as Iwkowa Commune could lose their landscape attractiveness with increased tourism development in the region.

More broadly, and on the methodological front, this study has illuminated just some of the complexity involved in evaluating and comparing the potential attractiveness of particular regions in terms of their tourism and recreation potential. Given this complexity (e.g., the fact that landscape aesthetics are not always well correlated with the tourism development potential), we conclude that a combination of evaluation methods such as those applied herein (Gołembski's [15] multivariate index of attractiveness to tourists and attractiveness to potential investors in the tourism industry, in conjunction with Wejchert's [32] impression curve), should be applied to reliably and comprehensively evaluate the relative attractiveness of different parts of a given region for tourism and recreation, for instance so as to inform planning decisions and the allocation of developmental funding.

Given that various countries, regions and companies are competing ever more intensely on the tourism market, such studies can serve as the basis for maintaining the dominant position of areas rich in natural attractions, cultural heritage and tourist base, as well as for enabling poorer areas to create various artificial attractions or market segmentation as part of tourist product development. Some of the data underpinning such the case studies, however, may become outdated and quite quickly cease to correspond to reality; therefore, it is advisable to repeat such research after a certain period of time, e.g., after a few years have passed. In this way we will obtain a picture of dynamics of the studied phenomenon in a certain period of time.

Author Contributions: A.Z.-W. and M.M. conceived the idea and planned the research. A.Z.-W. and M.M. collected the data, planned and carried out the statistical analyses. A.Z.-W. and M.M. contributed to the interpretation and visualization of the results. A.Z.-W. and M.M. were responsible for writing the manuscript. All authors have read and agreed to the published version of the manuscript.

Funding: This research was financed by the Ministry of Science and Higher Education of the Republic of Poland.

Acknowledgments: We would like to thank Mateusz Mizera for her support during preparation of this work, which was a part of her Master's thesis.

Conflicts of Interest: The authors declare no conflict of interest. The funders had no role in the design of the study; in the collection, analyses, or interpretation of data; in the writing of the manuscript, or in the decision to publish the results. 


\section{References}

1. Stoicea, D.M. Aspects of the impact of the economic and financial crisis on global tourism. Rev. Tinerilor Econ. 2020, 35, 61-69.

2. Livandovschi, R.; Melnic, I. The impact of COVID-19 on tourism. In Competitivitatea şi Inovarea în Economia Cunoaşterii; Academia de Studii Economice a Moldovei: Chişinău, Moldova, 2020; pp. 9-12, ISBN 978-9975-75-986-1.

3. World Tourism Organization. European Union Tourism Trends; UNWTO: Madrid, Spain, 2018.

4. Harba, J.N.; Parteca, M.; Bujduveanu, S. From Growth, to Chaos, to Uncertainty: The Impact of the COVID-19 Pandemic on European Tourism. In New Trends in Sustainable Business and Consumption, Proceedings of the 2020 Basiq International Conference, Messina, Italy, 4-6 June 2020; University of Messina: Messina, Italy; pp. 1249-1256.

5. EEA. Europe's Environment: The Third Assessment; European Environment Agency: Copenhagen, Denmark, 2003.

6. Tucki, A. Regionalne aspekty rozwoju turystyki na przykładzie województwa lubelskiego [Regional aspects of tourism development on the example of the Lublin region]. In Studia nad Turystyka [Tourism Studies]. Prace Geograficzne i Regionalne; Kurek, W., Faracik, R., Eds.; IGiGP, UJ: Kraków, Poland, 2007; pp. 267-279.

7. Kurek, W.; Mika, M. Waloryzacja Przestrzeni miejskiej Krakowa dla Potrzeb Turystyki [Valorization of Krakow's Urban Space for the Needs of Tourism]; IGiGP, UJ: Kraków, Poland, 2008; pp. 1-146.

8. Maliszewski, C. Metody planowania przestrzennego obszarów turystycznych i rekreacyjnych na poziomie lokalnym [Methods of spatial planning of tourist and recreational areas at the local level]. Człowiek Sr. 2016, 40, 59-82.

9. Kruczek, Z.; Zmyślony, P. Regiony Turystyczne. Podstawy Teoretyczne. Studium Przypadków [Tourist Regions. Theoretical Basics. Case Study], 2nd ed.; Proksenia: Kraków, Poland, 2014; pp. 1-304.

10. Ferrario, F. The Tourist Landscape: A Method of Evaluating Tourist Potential and Its Application to South Africa. Ph.D. Thesis, Department of Geography, University of California, Berkeley, CA, USA, 1976.

11. Poria, Y.; Butler, R.; Airey, D. Clarifying heritage tourism: A distinction between heritage tourism and tourism in historic place. Ann. Tour. Res. 2000, 28, 1047-1049. [CrossRef]

12. Mason, P. Tourism Impacts, Planning and Management, 1st ed.; Butterworth-Heinemann: Oxford, UK, 2003 ; pp. 1-272.

13. Scheyvens, R.; Biddulph, R. Inclusive tourism development. Tour. Geogr. 2018, 20, 589-609. [CrossRef]

14. Ziernicka-Wojtaszek, A.; Zawora, T. Wybrane metody oceny atrakcyjności agroturystycznej terenów wiejskich [Selected methods pertaining to the assessment of agricultural tourism attractiveness of rural regions]. Infrastruct. Ecol. Rural. Areas 2011, 2, 235-245.

15. Gołembski, G. (Ed.) Regionalne Aspekty Rozwoju Turystyki [Regional Aspects of Tourism Development], 1st ed.; PWN: WarszawaPoznań, Poland, 1999; pp. 1-206.

16. Formica, S.; Uysal, M. Destination attractiveness based on supply and demand evaluations: An analytical framework. J. Travel Res. 2006, 44, 418-430. [CrossRef]

17. Korzeniewski, J.; Kozłowski, M. Development of tourism in Polish poviats in the years 2010-2017. Qual. Quant. 2020, 54, 1591-1612. [CrossRef]

18. Rząsa, K.; Ogryzek, M.; Źróbek, R. The land transfer from the State Treasury to local government units as a factor of social development of rural areas in Poland. Land 2019, 8, 170. [CrossRef]

19. Brossard, T.; Wieber, J.C.; Joly, D. Analyse visuelle systématique des paysages de cours d'eau par deux approches complémentaires. Rev. Géographique Lyon 1998, 73, 299-308. [CrossRef]

20. Brassley, P. On the unrecognized significance of the ephemeral landscape. Landsc. Res. 1998, 23, 119-132. [CrossRef]

21. Pietrzak, M.; Miedzińska, J.; Styperek, J. "Rzeczywista" Atrakcyjność Wizualna Krajobrazu Szlaków Turystycznych (na Przykładzie Szlaku im. Cyryla Ratajskiego w Wielkopolskim Parku Narodowym) ["Actual" Visual Attractiveness of the Landscape of Tourist Routes (on the example of the Cyryl Ratajski Trail in the Wielkopolska National Park)]. Probl. Ekol. Kraj. 1999, 5, 113-121.

22. Bell, P.A.; Greene, T.C.; Fischer, J.D.; Baum, A. Environmental Psychology, 5th ed.; Psychology Press: Hove, UK, $2004 ;$ pp. 1-654.

23. Richling, A. Główne kierunki badań nad krajobrazem [Key directions in landscape survey]. Probl. Ekol. Kraj. $2012,33,9-15$.

24. Kulczyk, S. Atrakcyjność turystyczna krajobrazu—Przykłady podejścia systemowego [Landscape tourist attraction-The examples of system approach]. Tur. Kult. 2014, 4, 6-15.

25. Galliano, S.J.; Loeffler, G.M. Scenery Assessment: Scenic Beauty at the Ecoregion Scale; Quigley, T.M., Ed.; General Technical Report PNW-GTR-472; (Interior Columbia Basin Ecosystem Management Project: Scientific Assessment); U.S. Department of Agriculture, Forest Service, Pacific Northwest Research Station: Portland, OR, USA, 2000; p. 30.

26. Zając, M.; Bałaga, K.; Janicki, G. Waloryzacja krajobrazu podmiejskiej wsi (okolice Lublina) dla potrzeb gospodarki przestrzennej [The valorisation of the landscape of a suburban village (Lublin's environs) for the purposes of spatial development]. Probl. Ekol. Kraj. 2014, 37, 77-86.

27. Lothian, A. Landscape and the philosophy of aesthetics: Is landscape quality inherentin the landscape or in the eye of the beholder? Landsc. Urban Plan. 1999, 44, 177-198. [CrossRef]

28. Bajerowski, T.; Sanetra, A.; Szczepańska, A. Wycena Krajobrazu: Rynkowe Aspekty Oceny i Waloryzacji Krajobrazu [Valuation of landscape: Market Aspects of the Assessment and Improvement of Landscape], 1st ed.; Educaterra: Olsztyn, Poland, 2000; pp. 1-81.

29. Wejchert, K. Elementy Kompozycji Urbanistycznej [Elements of Urban Composition], 2nd ed.; Arkady: Warsaw, Poland, 1984; pp. 1-279.

30. Wejchert, K. Przestrzeń Wokót Nas [The Space Around Us]; FIBA Noma Press: Katowice, Poland, 1993 ; pp. 1-232.

31. Cymerman, R.; Falkowski, J.; Hopfer, A. Krajobrazy Wiejskie: Klasyfikacja i Kształtowanie [Rural Landscapes: Classification and Planning]; AR-T: Olsztyn, Poland, 1992; pp. 1-116. 
32. Wejchert, K. Elementy Kompozycji Urbanistycznej [Elements of Urban Composition], 2nd ed.; Arkady: Warsaw, Poland, 1974; pp. 1-280.

33. Polska, A. Oceny estetyczne krajobrazu [The aesthetic landscape assessments]. In Niematerialne Wartości Krajobrazów Kulturowych [Intangible Values of Cultural Landscapes]. Pr. Kom. Kraj. Kult. 2011, 15, 185-192.

34. Wang, Y.; Xia, Z.; Chen, W. Aesthetic values in sustainable tourism development: A case study in Zhangjiajie National Park of Wuling Yuan, China. J. China Tour. Res. 2008, 4, 205-218. [CrossRef]

35. Beza, B. The aesthetic value of a mountain landscape: A study of the Mt. Everest Trek. Landsc. Urban Plan. 2010, 97, 306-317. [CrossRef]

36. Dong, R.; Dong, Z. Aesthetic evaluation of yardang landforms landscape: The Dunhuang Yardang National Geopark example. Sci. Cold Arid. Reg. 2018, 7, 265-271. [CrossRef]

37. Hoppstadius, F. Tourists' reflections on sustainability in a biosphere reserve landscape. Int. J. Tour. Res. 2019, 21, 560-573. [CrossRef]

38. Schirpke, U.; Altzinger, A.; Leitinger, G.; Tasser, E. Change from agricultural to touristic use: Effects on the aesthetic value of landscapes over the last 150 years. Landsc. Urban Plan. 2019, 187, 23-35. [CrossRef]

39. Kondracki, J. Geografia Regionalna Polski [Regional Geography of Poland], 3rd ed.; PWN: Warszawa, Poland, $2011 ;$ pp. 1-468.

40. Statistics Poland (GUS), Local Data Bank. Available online: https:/ / bdl.stat.gov.pl/BDL/start (accessed on 1 September 2021).

41. Prus, B.; Król, K. Ocena zastosowania wybranych metod taksonomicznych do klasyfikacji zjawisk społeczno-gospodarczych [Evaluation of using selected taxonomic methods to classify socio-economic phenomena]. Acta Sci. Pol. Form. Circumiectus 2017, 16, 179-197. [CrossRef]

42. Hakuć-Błażowska, A.; Pacek, N.; Kupren, K.; Furgała-Selezniow, G. Comparison of tourist attractiveness of rural and urban-rural communes of Elblag County. Studia Obsz. Wiej. 2018, 50, 81-99. [CrossRef]

43. Porteous, J.D. Environmental Aesthetics. Ideas, Politics and Planning, 1st ed.; Taylor \& Francis: London, UK, $2004 ;$ pp. 1-312.

44. Dakin, S. There's more to landscape than meets the eye: Towards inclusive landscape assessment in resource and environmental management. Can. Geogr. Le Ge 'Ographe Can. 2003, 47, 185-200. [CrossRef]

45. Surová, D.; Pinto-Correia, T. Landscape preferences in the cork oak Montado region of Alentejo, southern Portugal: Searching for valuable landscape characteristics for different user groups. Landsc. Res. 2008, 33, 311-330. [CrossRef]

46. Stephenson, J. The dimensional landscape model: Exploring differences in expressing and locating landscape qualities. Landsc. Res. 2010, 35, 299-318. [CrossRef]

47. Daniel, T.C.; Vining, J. Methodological issues in the assessment of landscape quality. In Human Behavior and Environment, 1st ed.; Altman, I., Wohlwill, J.F., Eds.; Springer: Boston, MA, USA, 1983; Volume 6, pp. 39-84.

48. Kupidura, A.; Łuczewski, M.; Kupidura, P. Wartość Krajobrazu. Rozwój Przestrzeni Obszarów Wiejskich [Landscape Value. Spatial Development of Rural Areas], 1st ed.; PWN: Warsaw, Poland, 2011; pp. 1-106.

49. Czubaszek, R.; Wysocka-Czubaszek, A.; Brzózko, A. Waloryzacja krajobrazu gminy wiejskiej Wysokie Mazowieckie [The assessment of the landscape quality of the Wysokie Mazowieckie rural commune]. Probl. Ekol. Kraj. 2016, 16, 81-93.

50. Pukowiec, K.; Kurda, W. Ocena atrakcyjności turystyczno-rekreacyjnej gmin powiatu lublinieckiego [Evaluation of the tourist and recreational attractiveness of the communes in the county of lubliniec]. Zesz. Nauk. Wyższej Szkoty Przymierza Rodz. Warszawie 2013, 11, 7-20.

51. Tokarska-Osyczka, A.; Iszkuło, G. Waloryzacja przyrodniczo-krajobrazowa, kulturowa oraz ocena atrakcyjności turystycznej gmin na terenie Pojezierza Międzychodzko-Sierakowskiego [Valorization of nature, landscape and cultural and tourist attractiveness rating communis in the Międzychodzko-Sierakowski Lakeland]. Zesz. Nauk. Inżynieria Sr. Uniw. Zielonogórski 2014, 153, 67-81.

52. Połucha, I.; Marks, E. Ocena walorów przyrodniczych i kulturowych gminy Reszel pod kątem rozwoju turystyki [The evaluation of the natural and cultural values of the municipality Reszel for tourism development]. Acta Sci. Pol., Adm. Locorum 2012, 11, 177-198.

53. Lee, C.F.; Huang, H.I.; Yeh, H.R. Developing an evaluation model for destination attractiveness: Sustainable forest recreation tourism in Taiwan. J. Sustain. Tour. 2010, 18, 811-828. [CrossRef]

54. Cracolici, M.F.; Nijkamp, P. The attractiveness and competitiveness of tourist destinations: A study of Southern Italian regions. Tour. Manag. 2008, 30, 336-344. [CrossRef]

55. Mazurski, K.R. Pojęcie krajobrazu i jego ocena [The concept of landscape and its assessment]. In Mijajace krajobrazy Polski, Dolny Ślask-Krajobraz Dolnoślaski Kalejdoskopem Jest ... [The passing landscapes of Poland, Lower Silesia-The Lower Silesian landscape A kaleidoscope It Is ... ], 1st ed.; Mazurski, K.R., Ed.; Proksenia: Kraków, Poland, 2012; pp. 11-18.

56. Dwyer, L.; Jago, L.; Forsyth, P. Economic evaluation of special events: Reconciling economic impact and cost-benefit analysis. Scand. J. Hosp. Tour. 2016, 16, 115-129. [CrossRef]

57. Markowski, J.; Bartos, M.; Rzenca, A.; Namiecinski, P. An evaluation of destination attractiveness for nature-based tourism: Recommendations for the management of national parks in Vietnam. Nat. Conserv. 2019, 32, 51-80. [CrossRef]

58. Krzymowska-Kostrowicka, A. Geoekologia Turystyki i Wypoczynku [Geoecology of Tourism and Recreation], 2nd ed.; PWN: Warsaw, Poland, 1999; pp. 1-239.

59. Scolozzi, R.; Schirpke, U.; Detassis, C.; Abdullah, S.; Gretter, A. Mapping alpine landscape values and related threats as perceived by tourists. Landsc. Res. 2014, 40, 451-465. [CrossRef]

60. Cho, S.; Poudyal, N.C.; Roberts, R.K. Spatial analysis of the amenity value of green open space. Ecol. Econ. 2008, 66, 403-416. [CrossRef] 
61. Domon, G. Landscape as resource: Consequences, challenges and opportunities for rural development. Landsc. Urban Plan. 2011, 100, 338-340. [CrossRef]

62. Senetra, A. Las jako istotny komponent przestrzeni w aspekcie opracowywania map wartości krajobrazów wiejskich [Forests as an important spatial element in elaboration of the esthetic value maps for rural landscapes]. Sylwan 2015, 159, 757-766.

63. Gracz, J.; Sankowski, T. Psychologia w Rekreacji i Turystyce [Psychology in Recreation and Tourism]; AWF: Poznań, Poland, 2004; pp. 1-262.

64. Malinowska, E. Wpływ atrakcyjności wizualnej krajobrazu na potencjał turystyczny Narwiańskiego Parku Narodowego i jego otuliny [The influence of visual quality of landscape on the touristic potential of the Narwiański National Park and its buffer zone]. Probl. Ekol. Kraj. 2010, 27, 277-285.

65. Adamiec, P. Wykorzystanie walorów przyrodniczo-krajobrazowych dolin rzecznych Lublina w rekreacji [The role of natural and landscape values of Lublin rivers in recreation]. Nauka Przyr. Technol. 2008, 2, 1-9. Available online: http://www.npt.up-poznan. net/tom2/zeszyt4/art_47.pdf (accessed on 18 September 2021).

66. Mordwa, S. Krzywa wrażeń dla ulicy Piotrkowskiej w Łodzi [Piotrkowska street in Łódź sensations curve]. Acta Univ. Lodz. Folia Geogr. Socio-Oeconomica 2009, 10, 89-98.

67. Pisarek, M.; Gargała-Polar, M. Waloryzacja przyrodnicza i kulturowa żółtego szlaku turystycznego „Dookoła Rzeszowa” [Natural and cultural investigation of the yellow tourist route "Dookoła Rzeszowa"]. Zesz. Nauk. Tur. Rekreac. 2019, 1, 115-123.

68. Wiatrak, A.P. Zagadnienia rozwijania turystyki w strategiach rozwoju lokalnego [Issues of developing tourism in local development strategies]. In Instytucjonalne i Strukturalne Aspekty Rozwoju Rolnictwa i Obszarów Wiejskich [Institutional and Structural Aspects of Agricultural and Rural Development], 1st ed.; Przygodzka, R., Gruszewska, E., Eds.; Wyd. Uniwersytetu w Białymstoku: Białystok, Poland, 2020; pp. 131-144.

69. Butler, R.W. Sustainable tourism: A state of the art review. Tour. Geogr. 1999, 1, 7-25. [CrossRef]

70. Para, A. Zasady zrównoważonego rozwoju turystyki-Bariery i szanse dla branży turystycznej [Principles of sustainable development-Barriers and opportunities for tourism industry]. In Zrównoważony Rozwój w Turystyce w Różnych Perspektywach Analitycznych [Sustainable Development in Tourism in Various Analytical Perspectives], 1st ed.; Kozikowska, M., Ed.; Zeszyty Naukowe. Turystyka i Rekreacja 11(1), Wyższa Szkoła Turystyki i Języków Obcych: Warszawa, Poland, 2013; pp. 5-16.

71. Przeorek-Smyka, R. Determinanty prawne zrównoważonego rozwoju turystyki w Unii Europejskiej i w Polsce. Wybrane problemy [Law determinants of sustainable tourism development in the UE and Poland. Selected problems]. In Gospodarka Turystyczna w Regionie. Rynek Turystyczny_Wspótczesne Trendy, Problemy i Perspektywy Jego Rozwoju [Tourist Economy in the Region. Tourist Market - Contemporary Trends, Problems and Prospects for Its Development], 1st ed.; Rapacz, A., Ed.; Pr. Nauk. Uniwersytetu Ekonomicznego we Wrocławiu: Wrocław, Poland, 2013; Volume 304, pp. 241-252. 